\title{
Climate Risk Assessment Services for agri-food sector
}

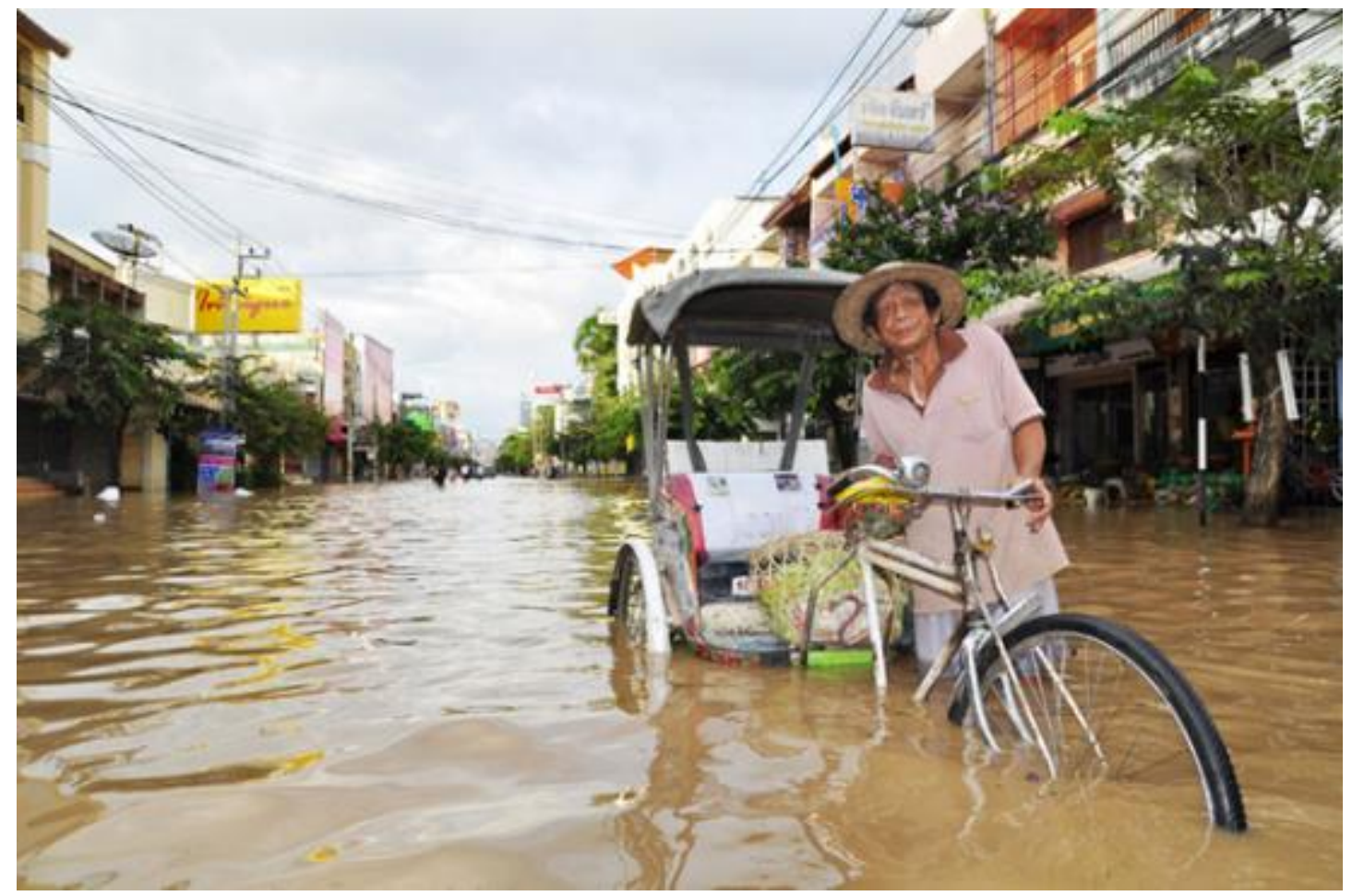

A. Groot $^{1}$, K. de Bruin ${ }^{1}$, J. Bolt ${ }^{1}$, P. Verwey ${ }^{1}$, E. Daniels ${ }^{1}$, R. Hutjes ${ }^{1}$

${ }^{1}$ WENR - Wageningen Environmental Research

This research was funded by the Dutch Ministry of Agriculture, Nature and Food Quality Project number KB-24-002-047

Wageningen Environmental Research

Wageningen, January 2019 
Groot, A., K. de Bruin, J. Bolt, P. Verwey, E. Daniels and R. Hutjes, 2019. Climate Risk Assessment Services for agri-food sector. Wageningen, Wageningen Environmental Research.

Abstract NL

Abstract UK

Keywords: climate change, climate risk, assessment services, agri-food sector, value chain

The pdf file is free of charge and can be downloaded at https://doi.org/10.18174/471420 or via the website www.wur.nl/environmental-research (scroll down to Publications - Wageningen Environmental Research reports). Wageningen Environmental Research does not deliver printed versions of the Wageningen Environmental Research reports.

(9) 2019 Wageningen Environmental Research (an institute under the auspices of the Stichting Wageningen Research), P.O. Box 47,6700 AA Wageningen, The Netherlands,

$\mathrm{T}+31(0) 3174807$ 00, www.wur.nl/environmental-research. Wageningen Environmental Research is part of Wageningen University \& Research.

- Acquisition, duplication and transmission of this publication is permitted with clear acknowledgement of the source.

- Acquisition, duplication and transmission is not permitted for commercial purposes and/or monetary gain.

- Acquisition, duplication and transmission is not permitted of any parts of this publication for which the copyrights clearly rest with other parties and/or are reserved.

Wageningen Environmental Research assumes no liability for any losses resulting from the use of the research results or recommendations in this report.

Wageningen Environmental Research Report | ISSN 1566-7197

Photo cover: image bank Wageningen UR 


\section{Contents}

$\begin{array}{ll}\text { Samenvatting } & 5\end{array}$

$\begin{array}{ll}\text { Summary } & 6\end{array}$

$1 \quad$ Climate Risk Assessment $\quad 7$

$\begin{array}{lll}1.1 & \text { Introduction } & 7\end{array}$

$\begin{array}{lll}1.2 & \text { Climate risk assessment concept } & 7\end{array}$

1.3 Inventory of climate related assessment tools and data sets currently used by WENR researchers $\quad 8$

1.4 Inventory of existing climate related (risk) assessment tools and approaches 11

$\begin{array}{ll}\text { WENR's Climate risk assessment services } & 18\end{array}$

2.1 Process 19

2.2 Step 1 - Climate change assessment 20

2.2 Step 2 - Assessing impact climate change on water availability 26

2.3 Step 3 - Climate Change risk assessment 30

2.4 Step 4 - Identification of potential business case 34

5.1 Step 1.1 - Questionnaire Value chain mapping 42

5.2 Step 1.2 - Questionnaire Identification climate variables $\quad 43$

5.3 Step 2.3 - Assessment of climate change impact on water availability and crop production $\quad 46$

5.4 Step 3.1 - Identification of potential climate /weather related risks 48

$\begin{array}{lll}5.5 & \text { Step } 3.2 \text { - Risk prioritisation } & 50\end{array}$ 


\section{Samenvatting}

Dit rapport beschrijft een aanpak en services die geleverd kunnen worden door medewerkers van Wageningen Environmental Research om partijen binnen agrifood ketens te helpen inzicht te krijgen in risico's die hun business loopt als gevolg van klimaatverandering en hoe men deze risico's zou kunnen verminderen en/of vermijden. De diensten die WEnR kan leveren omvatten: de ontwikkeling en visualisatie van klimaatprojecties voor specifieke regio's, het bepalen van effecten van klimaatverandering op water beschikbaarheid en gewasproductie en het analyseren van risico's voor ketenpartijen en hun business als gevolg van klimaatverandering. Ook kan WEnR helpen bij het identificeren en analyseren van businessideeën die klimaatrisico's kunnen verminderen, maar die ook nieuwe kansen kunnen bieden.

De 'climate risk assessment' aanpak die in dit rapport wordt beschreven wordt op dit moment toegepast in het Climate Smart Africa - East Africa project waarin WEnR participeert. In dit project worden sommige zogenaamde 'climate risk assesssment activiteiten' uitgevoerd door WEnR, anderen door projectpartners. 


\section{Summary}

Climate change and climate variability pose high risks to the agri-food business as it threatens ecosystems and impacts the natural capital on which companies depend. Agri-food companies have already suffered weather-related impacts in recent years, and most have seen an intensification of such impacts. Meanwhile, farming- and other communities on which the agri-food businesses depend for their supplies of agricultural commodities, raw materials and work force are also highly affected.

Recognizing the problem, identifying climate related risks in the supply chain and responding with adaptation measures can help agri-food businesses to minimize their risks and strengthen resilience. Responding to the effects of climate change will also provide opportunities for innovative climate resilient products and services and open up new markets. For example, insurance agencies are already developing innovative climate-insurance products for communities at increased risk of weather-related natural disasters. New water-use efficient irrigation technologies are being developed and deployed to address increased water stress.

This report describes a set of services WEnR can deliver to assist stakeholders in an agri-food chain to assess climatic risks and potential adaptation strategies to mitigate these risks. These services include development of regionalised / bias corrected climate change projections, climate change impact assessments, assessment of climate /weather related risks, assessment of potential business cases mitigating climatic risks.

The services i.e. climate risk assessment described in this report are current being delivered in the Climate Smart Agriculture - East Africa project, but do have wider application opportunities as being described in the last chapter. Some of the climate risk activities are being carried out by WEnR, others by project partners. 


\section{$1 \quad$ Climate Risk Assessment}

\section{$1.1 \quad$ Introduction}

This report describes a set of services Wageningen Environmental Research can deliver to assist stakeholders in agri-food chains to assess climate/weather related risks and potential adaptation strategies to mitigate these risks. These services include development of regionalised / bias corrected climate change projections, climate change impact assessments, assessment of climate /weather related risks, assessment of potential business cases mitigating climatic risks. This reports describes these services as a package 'climate risk assessment services', which is currently being delivered in the Climate Smart Agriculture - East Africa project ${ }^{1}$.

Climate change and climate variability pose high risks to the agri-food business as it threatens ecosystems and impacts the natural capital on which companies depend. Rising temperatures, changing rainfall patterns, and more severe weather events are being observed. Agri-food companies have already suffered weather-related impacts in recent years, and most have seen an intensification of such impacts. Meanwhile, farming- and other communities on which the agri-food businesses depend for their supplies of agricultural commodities, raw materials and work force are also highly affected.

Recognizing the problem, identifying climate related risks in the supply chain and responding with adaptation measures can help agri-food businesses to minimize their risks and strengthen resilience. Responding to the effects of climate change will also provide opportunities for innovative climate resilient products and services and open up new markets. For example, insurance agencies are already developing innovative climate-insurance products for communities at increased risk of weather-related natural disasters. New water-use efficient irrigation technologies are being developed and deployed to address increased water stress.

Climate resilience in agricultural supply chains is a complex and relatively new field of study. The uncertainty around climate change in combination with the complexity of these food chains encompassing multiple countries, large number of farmers and individual organisations, and an extensive transport network makes it difficult to decide on where to act, with whom and how? However, at the same time a growing number of actors in the supply chain would like to know more about the likely impact of climate change and variability on their business. They are very much interested in adaptation strategies that mitigate climate related risks, are cost effective and/or increase their business opportunities. WEnR can offer services that meet these requirements and interests.

\subsection{Climate risk assessment concept}

What is climate risk and what is a climate risk assessment? Climate risk is conceptualised by the Intergovernmental Panel on Climate Change. Figure 1 visualises the core concepts of climate risk, and each term is further specified below based on the glossary from the most recent IPCC report, the Special Report: Global Warming of $1.5^{\circ} \mathrm{C}$ (IPCC, 2018 - Glossary):

- $\quad$ Risk - The potential for adverse consequences where something of value is at stake and where the occurrence and degree of an outcome is uncertain. In the context of the assessment of climate impacts, the term risk is often used to refer to the potential for adverse consequences

\footnotetext{
${ }^{1}$ http://www.snv.org/project/climate-smart-agriculture-east-africa-csa-ea
} 
of a climate-related hazard, or of adaptation or mitigation responses to such a hazard, on lives, livelihoods, health and well-being, ecosystems and species, economic, social and cultural assets, services (including ecosystem services), and infrastructure. Risk results from the interaction of vulnerability (of the affected system), its exposure over time (to the hazard), as well as the (climate-related) hazard and the likelihood of its occurrence.

- Hazard - the potential occurrence of natural or human-induced physical event or trend that may cause loss of life, injury, or other health impacts, as well as damage and loss to property, infrastructure, livelihoods, service provision, ecosystems and environmental resources.

- Exposure - the presence of people; livelihoods; species or ecosystems; environmental functions, services and resources; infrastructure; or economic, social, or cultural assets in places and settings that could be adversely affected

- Vulnerability - The propensity or predisposition to be adversely affected. Vulnerability encompasses a variety of concepts and elements including sensitivity or susceptibility to harm and lack of capacity to cope and adapt

Risk assessment - The qualitative and/or quantitative scientific estimation of risks. (IPCC, 2018)

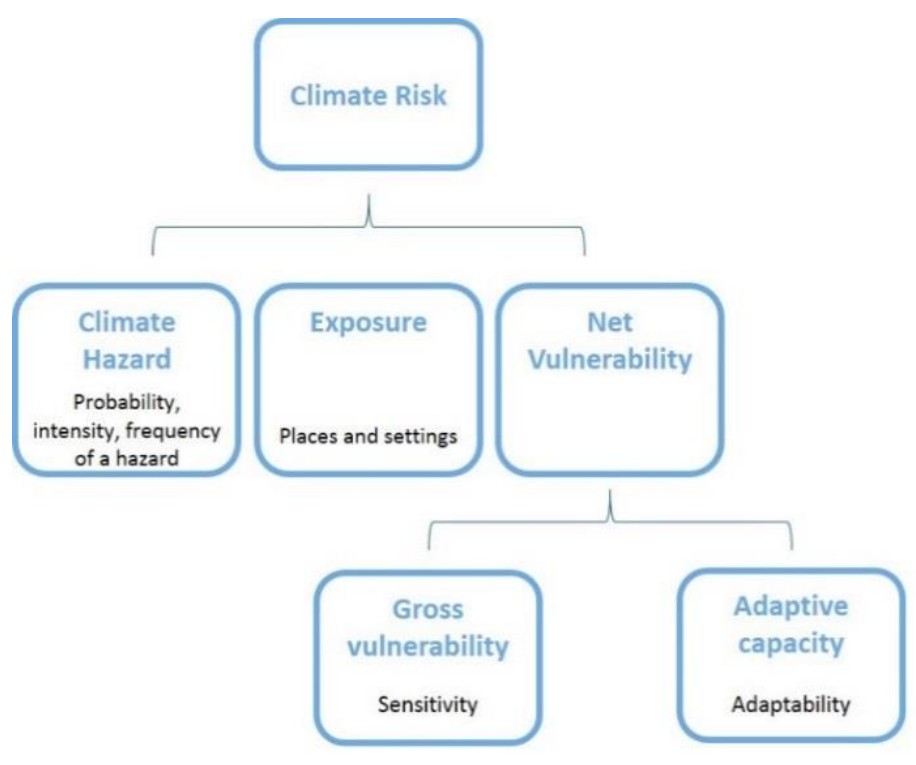

Figure 1. Core concepts of Climate Risk (IPCC, 2018 and CRIS, 2017)

\subsection{Inventory of climate related assessment tools and data sets currently used by WENR researchers}

A quick inventory of climate related assessment services, currently in use by researchers from WEnR shows different approaches, methods and tools addressing different aspects and scales. Most of these e services aim to support climate change adaptation, others focus on mitigation. The list hereafter shows examples of these services:

- Assessment of critical climate-stress moments: critical climate-stress moments are defined as those moments when households, communities, and the livelihood systems they depend on, are especially vulnerable to climate and weather-related risks and hazards. These include events at different spatial and temporal scales. Critical stress moments are a combination of (context-) specific present and past conditions, in which climate stresses are particularly likely to be risky 
and adverse to a particular household or community and the livelihood system they depend on. A 'moment' refers to a time period shorter than a year. A 'moment' may be days, weeks, or even months. A critical-moments assessment aims to support community members and adaptation planners in the development of more tailored, climate-change adaptation responses by identifying:

1. The specific climate conditions under which a critical moment occurs and how are such occurrences perceived by those experiencing them? What are their temporal and spatial scales, and how do these relate to climate trends? The information on weather and climate variability, climate change, and specific thresholds associated with critical moments can be used to tailor the analysis of climate-change models and to inform, tune, and interpret the outputs of (hydrological) effect models.

2. The socio-economic and political drivers of vulnerabilities giving rise to critical moments, as experienced and perceived by the most vulnerable and by a range of stakeholders at local level.

3. The effectiveness of current coping strategies to overcome critical moments.

Critical climate-stress moments assessments were successfully carried out in the Himalayan Adaptation, Water and Resilience (HI-AWARE) Research in 2016-2018 (Groot et al., 2017)

- Adaptation Turning Points analysis (Werners et al., 2018): is a proactive approach to assess adaptation needs and encourage timely adaptation. The approach focuses on identifying whether and when the performance of policies, management, and social-cultural practices drops below a decisive level due to climate change, and adaptation is required. The moment at which a decisive change in performance is reached is called an 'adaptation turning point'. An assessment of 'adaptation turning points' aims to contribute to adaptation by:

1. Identifying and communicating stakeholder relevant implications of climate change to raise awareness.

2. Giving guidance to adaptation planning, in particular to the identification of adaptation needs, the manifestation these adaptation needs through time and the timeliness of responses.

The assessment of turning points shows there is an imperative to act, and it aims to help proactively and timely plan alternative strategies. In cases with a development or implementation deficit and where the performance of the existing policies and practices is already unsatisfactory, the turning point lies in the past. If, in these cases, changes can be attributed to climate change, the assessment of turning points helps identify the adaptation gap. With respect to new practices, the assessment of turning points shows when these practices become viable in order to facilitate a smooth transition to alternative systems and practices. For development policies, an adaptation turning point assessment asks whether development goals are achievable under climate change and can be. A turning points analyses is successfully carried out in the Himalayan Adaptation, Water and Resilience (HI-AWARE) Research in 2016-2018 (Werners et al., 2018).

- Participatory vulnerability assessments: a multi-level and participatory approach to develop adaptation options to deal with climate related risks in a manner that contributes to stakeholder engagement, understanding of the risks, identification of the adaptation responses as well as prioritization and risk reduction. It involves stakeholders from different administrative acknowledging different perceptions and experiences with climate change (impacts) and priorities in adaptation options (Bhadwal et al., 2013). Participatory vulnerability assessments have been carried out in, amongst others, the FP7 project Highnoon.

- Climate vulnerability mapping: Using existing data to visualise climate risk information for different regions with large investments in agri-business. Develop tailor made regional maps that show impact of climate change scenario's for indicators like temperature rise, changing rainfall patterns and extreme events (drought, heat stress). Figure 2 provides for example details on the predicted reduction in agricultural production due to water shortage around the world. 


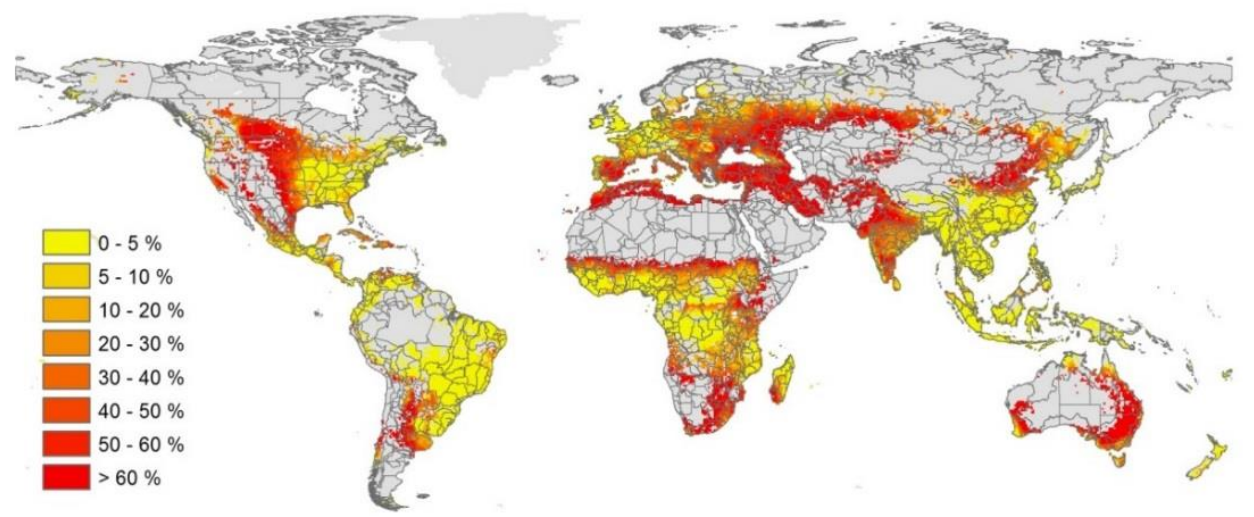

Figure 2. Projected water yield gap on rainfed agricultural areas in 2050 (RCP6.0 with SSP2). The water yield gap is defined as the difference between actual yields and potential yield in the absence of water constraints (Ligtvoet, 2018).

- Climate (adaptation) policy analysis: At WenR different projects have focussed on analysing (national) climate change policies and strategies. For example, Biesbroek et al.,2010 analysed and compared different national climate change (adaptation) strategies. Factors used in the analyses included: factors motivating and facilitating the development of a national adaptation strategy; the scientific and technical support needed for the development and implementation of such a strategy; the role of the strategy in information, communication and awareness-raising of the adaptation issue; new or existing forms of multi-level governance to implement the proposed actions; how the strategy addresses integration and coordination with other policy domains, and how the strategy suggests the implementation and how the strategy is evaluated.

- Climate awareness training (Coninx, 2017): events for risk managers, as part of a climate risk assessment service for climate resilient investments. Tailored made in-company training programme are organised for risk managers in order to:

- Raise awareness of climate change and its likely impacts on agri-food supply chains

- Understand climate risk and (social, economic and environmental) effects of climate change on agri-food business

- Translate climate risk to risk for investment decisions

- Identify user requirements for a climate risk tool to support investment decisions

- Sector transform (Coninx, 2017): use of scenarios showing possible futures for society under different climate change impacts. These scenarios are developed in a participatory way and used to discover how climate change may impact different stakeholders in a value chain of a specific sector. This method has been used, amongst others, with Vernof (Blomsma et al., 2016). Vernof, the association of Dutch producers of edible oils and fats, wished to help their members to become climate-proof. For them WEnR offered the Sector Transform, a participatory scenario workshop for the sector, to discuss with members how they view climate change and how they would like to see their sector developing in that context. The service delivered is a participatory scenario development process followed-up with visuals of workshop outcomes for further engagement (References: https://www.wur.nl/en/newsarticle/Voedselproductie-in-2050.htm and Report available: https://www.mvo.nl/media/duurzaamheid/rapport_klimaattop.pdf)

- Interactive climate atlas: maps the (primary and secondary) effects of climate change for a specific region. The atlas provides insights into the opportunities and challenges that can be found in an area. The user itself can combine climate and vulnerability maps by using buttons in the atlas that enable users to switch "on" and "off" different climate effects and vulnerable sectors and objects for different climate change scenarios. Among others, interactive atlases are developed for Netherlands (http://www.klimaateffectatlas.nl/), the Rotterdam and Haaglanden regions and for the city of Rotterdam.

- Climate ateliers: Climate effect atlas can be applied in a participatory setting i.e. an interactive design workshop in which climate change knowledge is used to support spatial planning or 
strategy development. The objective of the climate atelier is to make the effects of climate change tangible and to develop a concrete perspective for climate action. Researchers, policy makers, and stakeholders can jointly explore important effects in the climate effect atlas. This supports the development of multi-level adaptation strategies.

- Cool farm tool - The tool is an online calculator for greenhouse gases, water and biodiversity for farming. The module for greenhouse gases quantifies on-farm greenhouse gas emissions and soil carbon sequestration, see Verzandvoort, et al. (2017).

WEnR also delivers (climate) data/data sets and information that can support, are part of or a follow up of a climate change (risk) assessment process:

- Copernicus Climate Change Service - Global users demonstrates showcases on each populated continent for inspiration and provide data with guidance in best practices for climatechange adaptation. The aim is to ensure user uptake of relevant and high-impact climate information world-wide, addressing sectors such as health, safety, water-security, transport, biodiversity, tourism, agriculture and food production. The project provides:

- Easy access and user guidance to state-of-the-art scientific data on climate-change impact,

- Tailoring of information based on user requests and co-design with climate experts,

- Maps, graphs and downloads of readily available climate impact indicators world-wide, and

- Showcases from site-specific indicator production, merging global data with local data/tools.

- The Copernicus Climate Indicators for Agriculture is a Copernicus Climate Change Service contract which develops a set of operational services with high-impact climate derived information aimed at the agricultural and food sector in order to enable them to make informed decisions. End-users from different market segments are involved to provide market information and address global aspects of food security. Proven state of the art technologies on earth observation are combined with crop modelling to render crop-climate data for regional and global operating agribusinesses (commodity trading), water and irrigation agencies, agricultural policy and administration, and the food security research community.

- Climate change adaptation as business opportunity: CCA presents a wealth of opportunities for business and society. In different projects and programmes adaption strategies are analysed and developed from a business perspective. For example: in the Climate Smart Agriculture (CSA) Booster: a Climate KIC flagship to develop services to support transition in agriculture and food sector to climate change in Europe (Verzandvoort et al., 2017) and in 'scaling of CSA': a CCAFS funded project analysing business models of SMEs' as mechanisms for scaling CSA (Groot et al., 2017).

\subsection{Inventory of existing climate related (risk) assessment tools and approaches}

To support the development of a climate change risk assessment (CRA) tool for the agri-food business, a quick inventory of already existing CRA has been made. Table 1 provides details of climate risk assessments that focus more specifically on value chains/agricultural sector. It shows the provider of the tool, some characteristics and highlights that may be useful to incorporate in the WENR CRA tool. The table also helps to design an CRA service for WENR that has added value comparing it with other existing CRAs and to better position the WENR CRA tool in the CRA community. 


\begin{tabular}{|c|c|c|}
\hline $\begin{array}{l}\text { Services } \\
\text { provider }\end{array}$ & Approach- characteristics & Highlights \\
\hline 427 & $\begin{array}{l}\text { - Compares the relative exposure and sensitivity of key } \\
\text { commodities and producer countries to identify hotspots. } \\
\text { Models supply chain using hybrid multi-regional input-output } \\
\text { and life cycle analysis models to map supplier locations and } \\
\text { identify key industries } \\
\text { - Assesses country risks, natural resources risks, extreme weather } \\
\text { risk and industry risks. So industry risks are defined on the basis } \\
\text { of extreme weather events, water availability, and energy } \\
\text { demand requirements over time } \\
\text { - Identifies hotspots and develop high-level recommendations to } \\
\text { increase your supply chain's resilience to climate impacts } \\
\text { Deliverables: Fully customizable and interactive dashboard for } \\
\text { hotspot visualization, report building and easy data filtering }\end{array}$ & 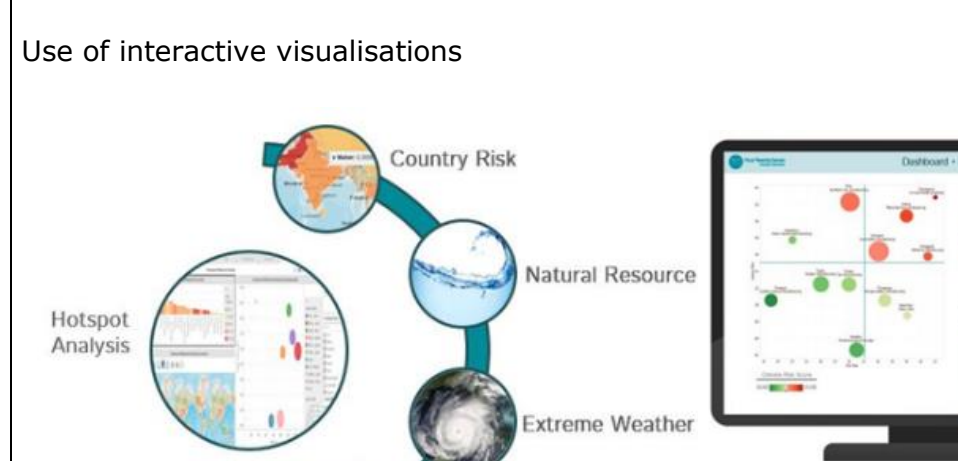 \\
\hline $\begin{array}{l}\text { IFAD/ } \\
\text { CGIAR }\end{array}$ & $\begin{array}{l}\text { - https://www.ifad.org/documents/10180/30b467a1-d00d-49af- } \\
\text { b36b-be2b075c85d2 } \\
\text { Checklist of how value chain interventions might produce climate- } \\
\text { resilient outcomes (input supply, production, post harvesting... } \\
-\quad \text { E.g. Financial services Lack of upfront capital may be a } \\
\text { major drawback for farmers to adopt climate-resilient } \\
\text { practices } \\
\text { - Opportunities for reaching scale with climate risk management in } \\
\text { value chain project designs } \\
\text { Inclusiveness }\end{array}$ & 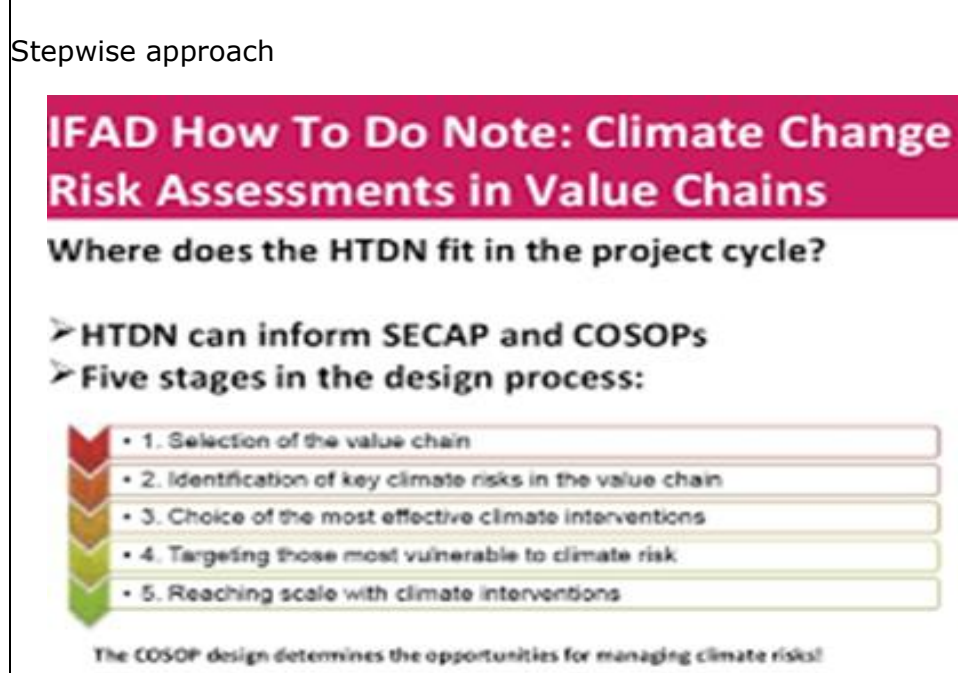 \\
\hline
\end{tabular}




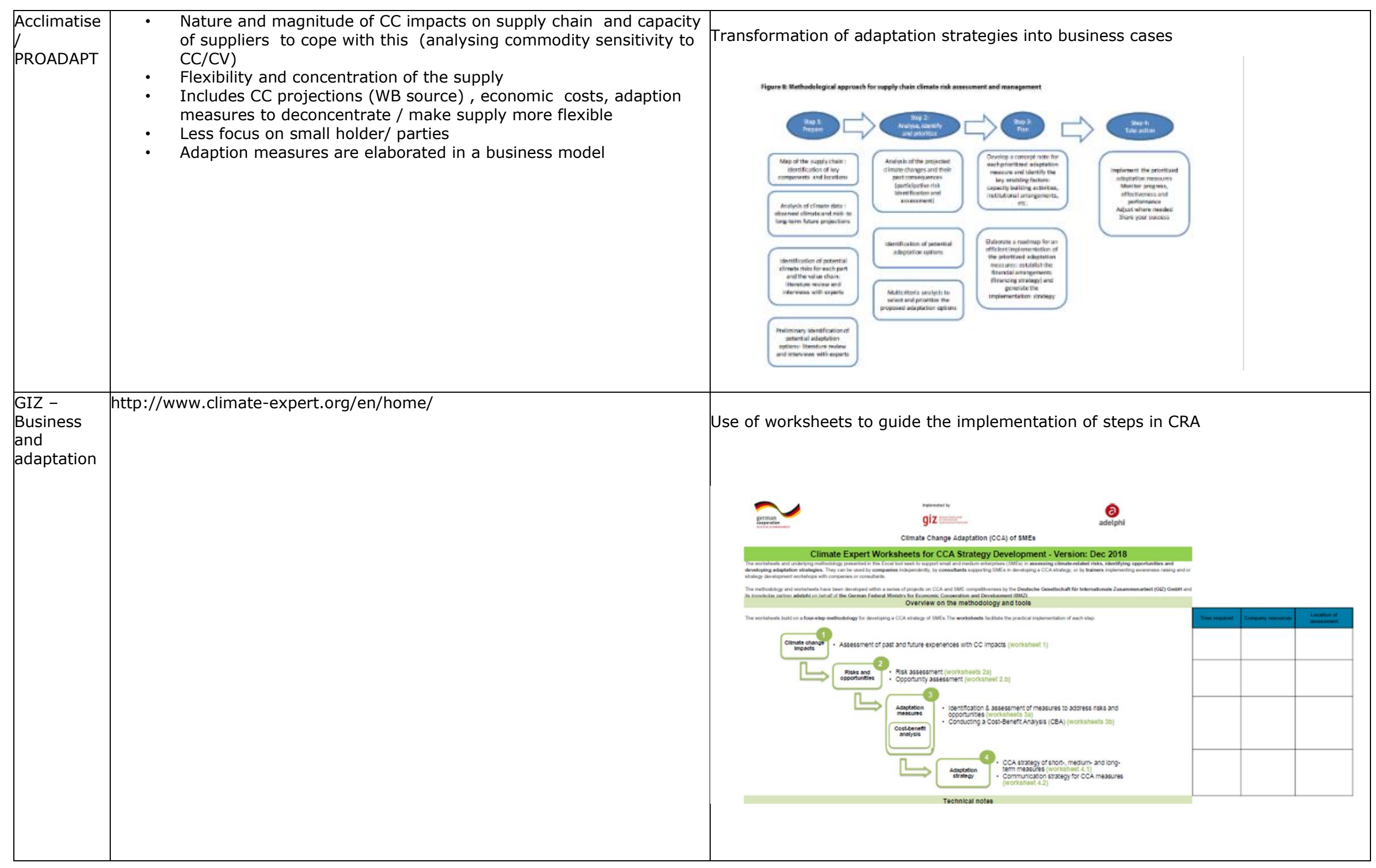




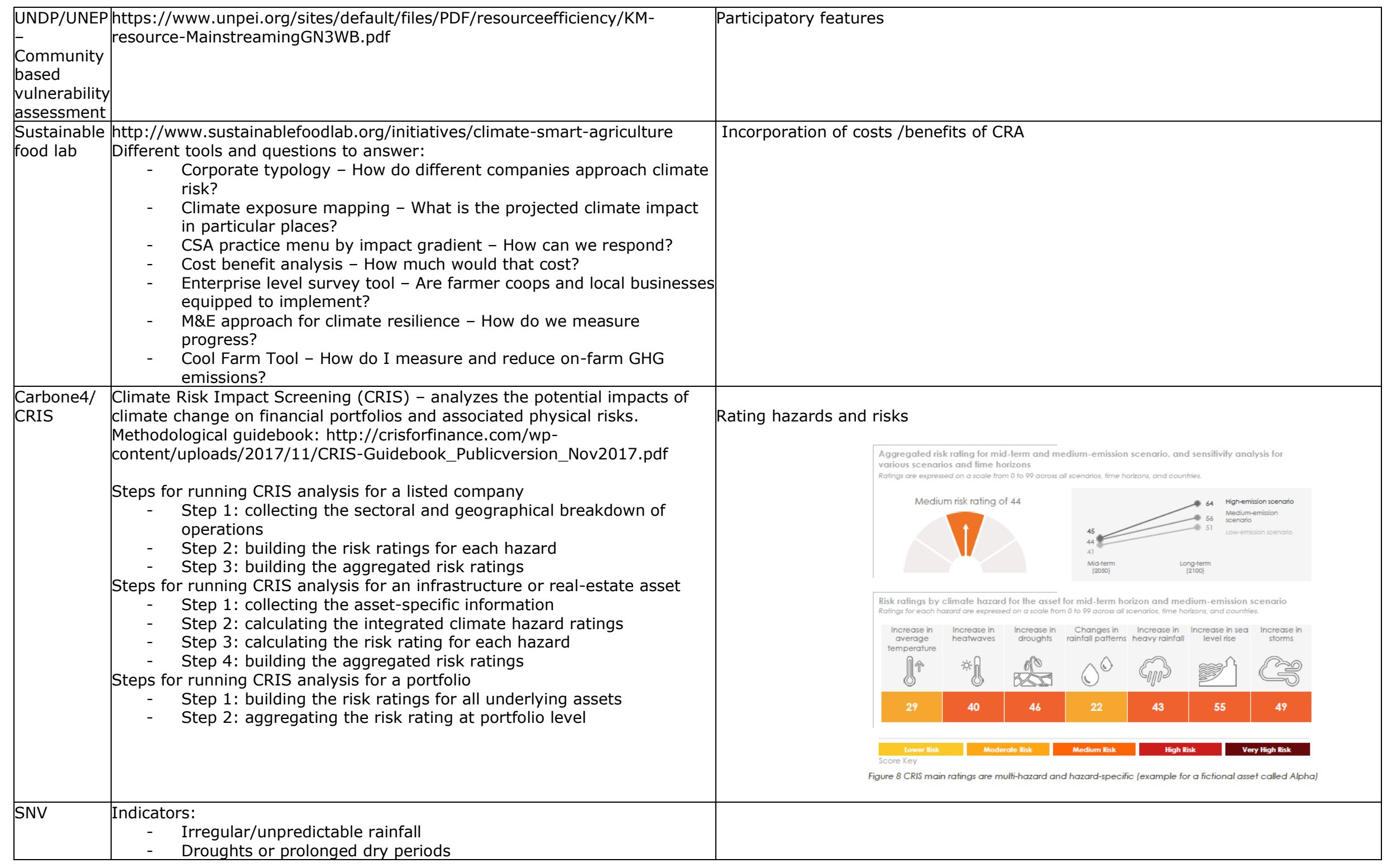




\begin{tabular}{|c|c|c|}
\hline $\begin{array}{cl}\text { - } & \text { Heavy rains } \\
\text { - } & \text { Higher temperatures/heat } \\
\text { Vulnerability assessment - climate change impact } \\
\text { - } \quad \text { What changes in weather patterns do the VC actors notice? } \\
\text { - } \quad \text { How are actors affected by climate change? } \\
\text { - } \quad \text { What climate trends/events have most impact? } \\
\text { - } \quad \text { What is the impact on their business/processes/resources? } \\
\text { Vulnerability assessment - adaptive capacity } \\
\text { - } \quad \text { How do actors respond to climate change? } \\
\text { - } \quad \text { Are they changing their practice because of climate change? } \\
\text { - } \quad \text { Do they (have) access (to) information on climate change? } \\
\text { - } \quad \text { Do they have sufficient knowledge on climate change? } \\
\text { - } \quad \text { Do they offer climate-smart services or products? } \\
\text { Vulnerability assessment - adaptation options } \\
\text { - } \quad \text { What adaptation options would they suggest? } \\
\text { - } \quad \text { How can they be implemented? } \\
\text { - } \quad \text { How can different actors along VC work together? }\end{array}$ & $\begin{array}{l}\text { Stepwise approach } \\
\text { Climate Risk Assessment Tool - Steps }\end{array}$ & $\begin{array}{r}\text { Fieldwork } \\
\text { Workshop } \\
\text { SNV }\end{array}$ \\
\hline
\end{tabular}

16 | Wageningen Environmental Research report 
Considering WEnR's current experiences and strengths with climate risk related services as well as the already existing cliamet risk tools delivered by other organisations, we decided that WEnR's CRA services highlighted in this report should:

- Apply recent evidence-based developments and products with respect to climate change projections, climate change impact assessments and climate data sets;

- Support participation of all stakeholders in a value chain in the assessment and prioritisation of climate related risks and adaptation strategies to mitigate these risks;

- Combine quantitative and qualitative assessments;

- Use visualisations to facilitate the communication of climate change information to the different stakeholders of value chain;

- Apply a stepwise approach, of which some are elaborated in worksheets (sees annexes 5.15.5) to support implementation;

- $\quad$ Elaborate adaptation measures identified to mitigate risks from a business case perspective.

In the next chapter, we will further describe WEnR's climate risk assessment services. We elaborate those current being applied in the Climate Smart Agriculture - East Africa project. Some of these are being carried out by WEnR, others by other project partners. These climate risk assessment services, however do have wider application opportunities than only the CSA -East Africa project. Market potentials for WEnR's climate risk assessment services are being described in the last chapter. 


\section{WEnR's Climate risk assessment services}

This chapter describes climate risk assessment services WEnR can deliver to support the actors in agricultural supply / value chains in:

- Creating awareness on the impact of climate change

- Identifying, assessing and prioritising climate related risks in the value chain

- Identifying opportunities for business cases addressing climate related risk

As mentioned before, these services are current being applied in the Climate Smart Agriculture - East Africa project.

\subsection{Principles}

WEnR delivers climate risk assessment services that respond to the needs of users of the information emerging from the assessment. Therefore each climate risk assessment may involve different tools depending the needs and context of the users. However, each climate risk assessment service is based on the following generic principles:

\section{Climate risk assessment combing quantitative and qualitative -participatory methods}

Risk assessments services incorporate a combination of various different methods, using quantitative models (e.g. climate or hydrological models) and qualitative (or participatory) methods (e.g. workshops with actors of value chain and other -climate/ agricultural- experts). Models or model based information will be used when quantitative information is required/desired to support decision making. The service will make use of recent developments in climate services (e.g. Copernicus Climate Change Services), water models, crop models and visualisations of climate related information. Participatory methods will be used to assess people's adaptive capacity to mitigate climate risks, prioritise risks, identify adaptation options and potential business ideas. For each step in a climate risk assessment process we discuss quantitative and qualitative options.

\section{Adaptation measures as business case}

Climate change and climate variability impacts agricultural productivity and water resources availability thus affecting the business of different actors in the value chain. Farmers and companies in a value chain experience benefits from investing in adaptation measures that increase resilience. The climate risk assessment services aims to support actors to identify adaptation measures that do not only address the ability to better manage and mitigate risk, but also to decrease costs, increase profits, create new markets, and/or to improve stakeholders' reputation.

\section{Gender sensitive}

Male and female farmers of different age groups are affected differently by climate change and respond differently to adaptation options, climate risk assessments will therefore be gender and age sensitive.

The climate risk assessment services described in this chapter are highly informed by discussions with partners of the project 'Climate Smart Agriculture in East Africa' that has recently started (October 2018). In this project a climate risk assessment of value chains in Kenya, Tanzania and Uganda is currently being carried out for which the services described in this document are being used. 


\subsection{Process}

WENR's climate risk assessment revolves around the use of climate information to cope with climate impacts on development, resources management and business. WENR's climate risk assessment combines a focus on climate information for better coping with current climate variability, with the use of climate projections assessing how these vulnerabilities may change in the future.

WEnR's climate risk assessment involves a process consisting of the following 4 steps (Figure 3 ):

1. Climate change assessment (including climate change projections)

2. Impact of climate change on water availability and crop production

3. Climate risks assessment in value chain

4. Identification of potential business case reducing climate risks

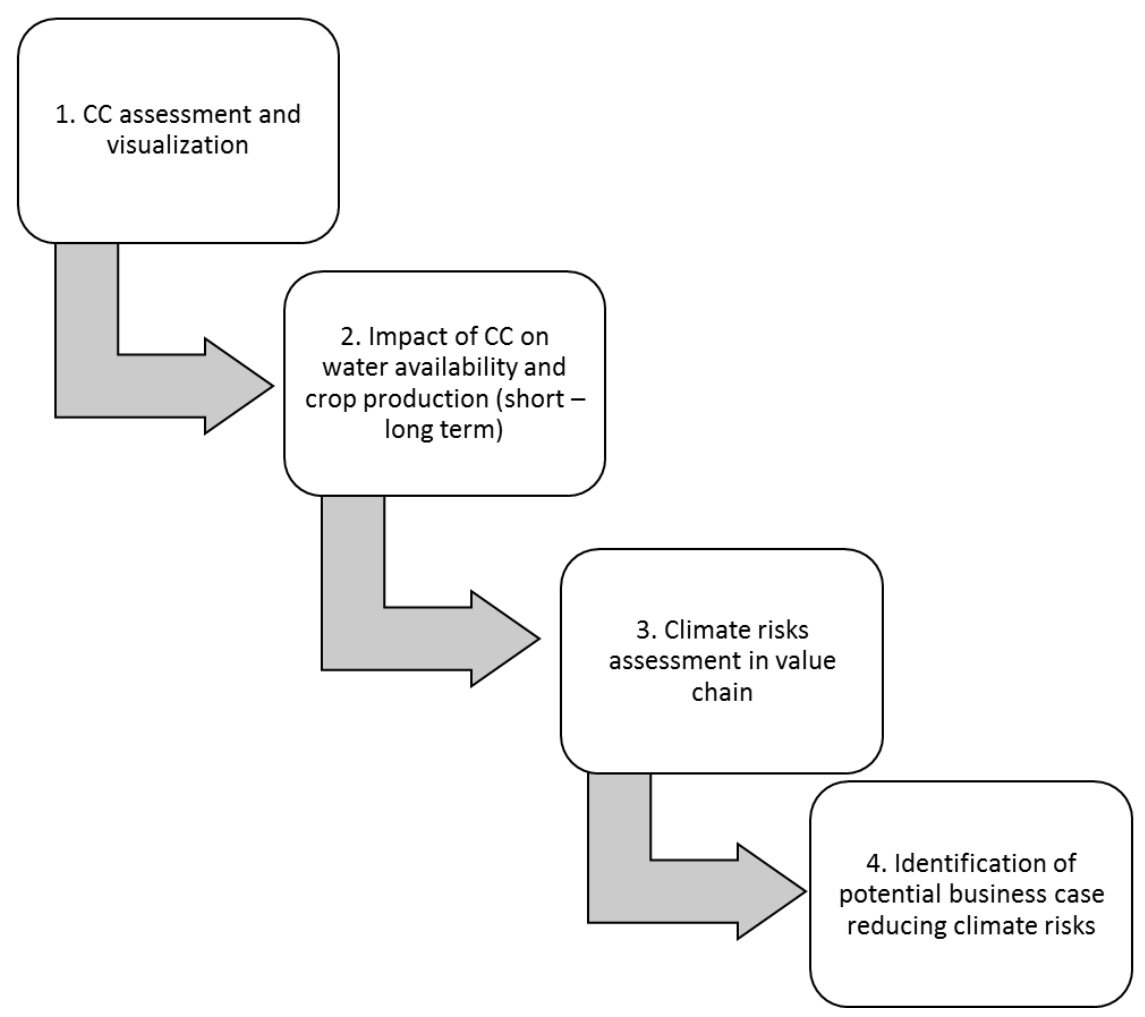

Figure 3: Climate risk assessment process - package of climate related services WEnR can deliver

Each step feeds into the next step. The ensemble of 4 steps is considered as a climate risk assessment. WEnR can facilitate a complete climate risk assessment process, but can also deliver services related to one single step (see chapter 1 ). In the CSA-East Africa, a complete climate risk assessment is being carried out. Different organisations are responsible for different steps. Each step involves interactions with stakeholders in the agri-food chain. Questionnaires that are used to facilitate this interaction are described in the next paragraphs as well as in the annexes 5.1-5.5. 


\subsection{Step 1 - Climate change assessment}

Step 1 Climate change assessment projects climate change for different climate change scenarios (RCPs) and targets climate variables (e.g. temperature, precipitation) that are relevant for stakeholders in the value chain. This first step also includes preparatory activities to set up the climate risk assessment such as defining its scope by mapping the agricultural supply chain and identifying the timeframe. It also includes the identification of climate variables, preferred temporal and spatial scales

\section{Activities}

- Map value chain and identify geographies (annex 5.1)

- Identify climate variables and develop insight into climate/ weather related hazards (annex 5.2)

- Climate change projections

- Visualise climate projections

\section{Outputs}

- Value chain map showing actors, activities and geographic areas involved

- Relevant climate variables (e.g. thresholds)

- (Interactive) maps showing (downscaled) climate change projections for relevant climate variables

, and the climate/ weather related hazards that actors currently experience. The first step results into a set of climate change projections (for different RCPs) including visualisations of these projections. The activities are briefly described and elaborated in separate annexes.

\section{Value chain mapping and identify geographies}

To define the scope of the climate risk assessment, the actors in the value chain, the main processes, used resources as well as the geographies will be visualised in one or more maps. Annex 5.1 shows a set of questions that are useful to map the actors of the value chain. It is important to consider differentiation of actors (men, women, youth, small farmers, medium size farmers, SMEs and large companies) and the location where they mainly run their business. Processes (production, trading, processing etc.), climate sensitive (natural) resources and infrastructure (e.g. roads, bridges) essential for these processes need to be mapped. Insight into these resources, infrastructure and their geographic locations will support the climate change impacts assessments (see figures 4 and 5 for examples). 


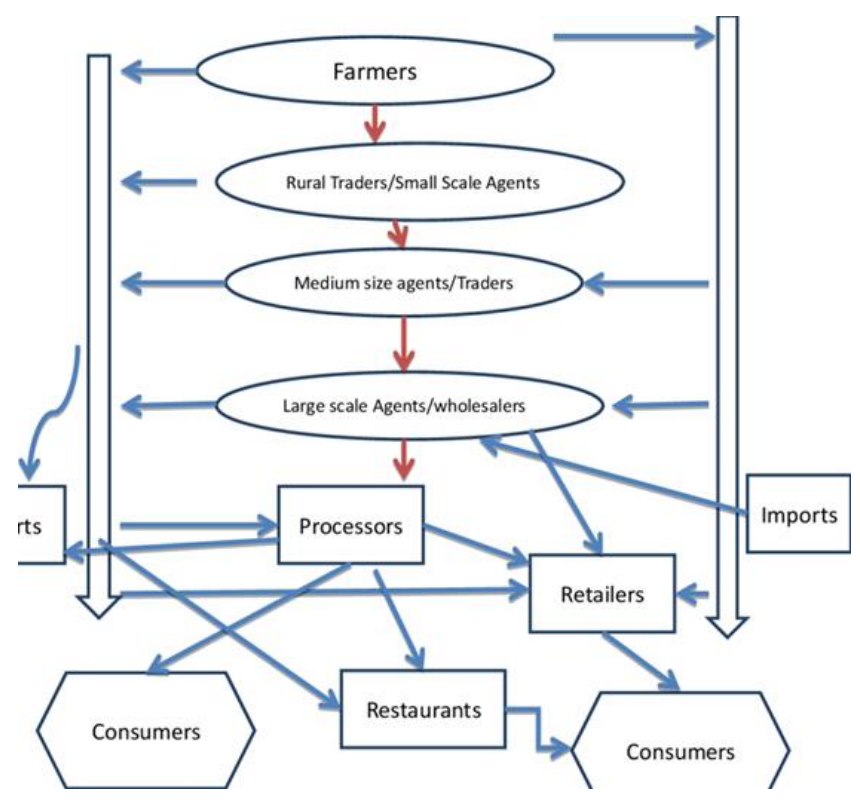

Figure 4: The Kenyan potato chain (Bornventure et al., 2018)

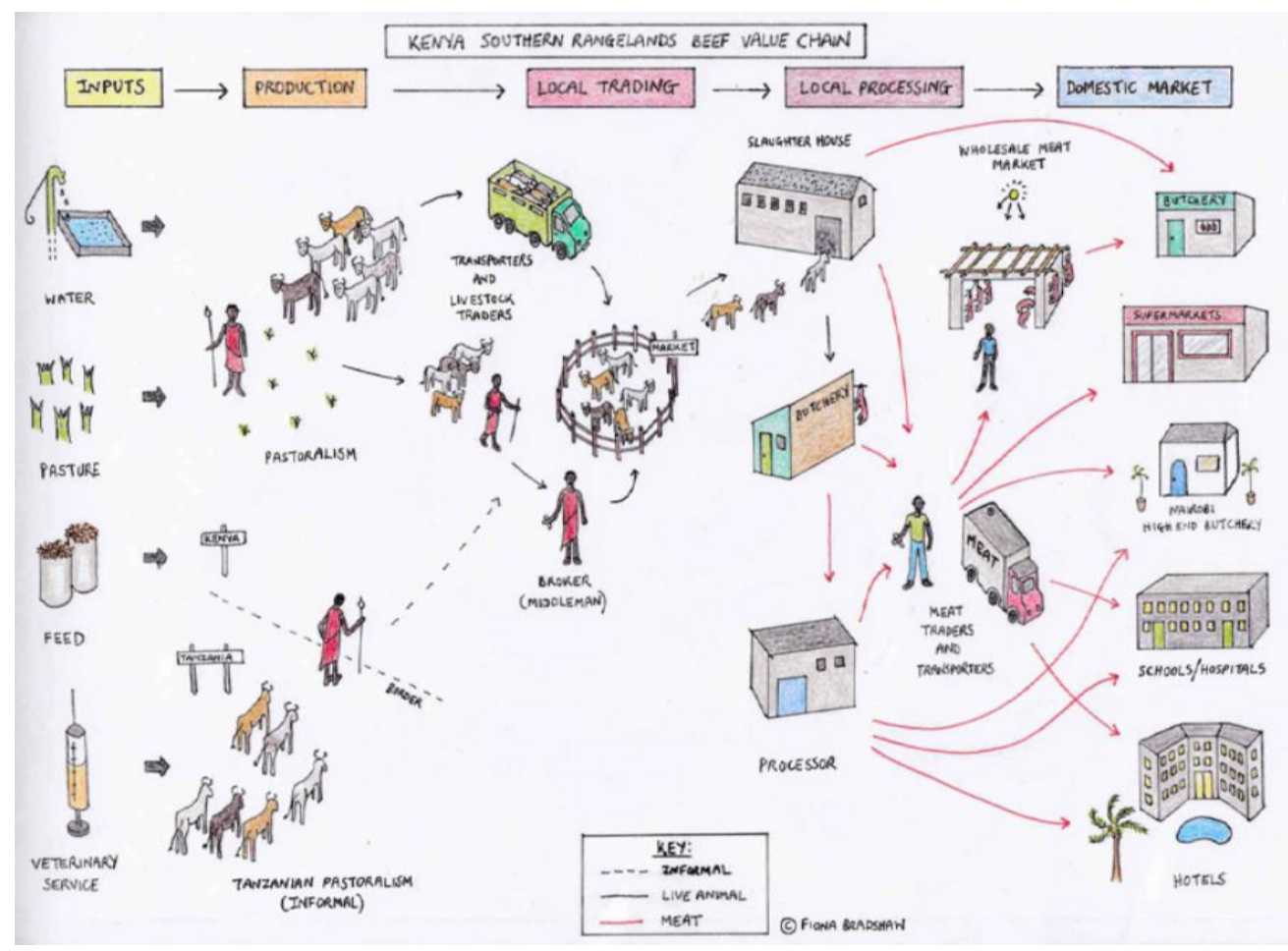

Figure 5: PRISE (2017). Value chain map for beef in Kenya

For the mapping of a value chain, use can be made of existing literature and interviews with actors of the value chain. Annex 5.1 provides examples of questions that can be used in interviews to map a value chain.

\section{Identifying climate variables and climate/weather related hazards}

The identification of climate variables (or indicators) serves two purposes:

- It will inform the climate change projections: Projections will be done for climate variables that are relevant for one or more actors in the value chain. Examples of climate variable are: min. night 
temperature, average day temperature, mean monthly precipitation or 10 consecutive days without rain

- Discussions with stakeholders in the value chain and other key-informants on climate variables provide insight into climate /weather related hazards adversely affecting (their) agri- businesses. These discussions also develop insight in the critical periods actors' business is most sensitive to and impacted by these hazards (e.g. drought may hinder sunflower processing companies)

It is very likely that different actors such as distinguished male or female farmers, highlight different climate variables as being important to them. Discussions with actors should always be gender and age sensitive: ensure women and men, young and old are interviewed as well. It is strongly recommended to conduct interviews with separate age and gender groups and to analyse answers according to gender and age differences.

To identify essential climate variables use can be made of existing literature and interviews with actors in the value chain and with other informants (e.g. climate change experts, experts in agronomy or hydrology). Annex 1.2 provide questions to be addressed to identify essential climate variables and to develop insight into climate/weather related hazards.

\section{Climate change projections for specific regions}

Climate change projections is the simulated response of the climate system to a scenario of future emission or concentration of greenhouse gases and aerosols, generally derived using climate models (IPCC, 2014). Climate projections are distinguished from predictions in order to emphasise that projections involve assumptions - concerning, for example, future socio-economic and technological developments, that may or may not be realised - and are therefore subject to substantial uncertainty. Climate change projections assess the future stage of our climate up to 2100.

Climate change projections involves multiple activities for which multiple data sets, multiple climate models and multiple Representative Concentration Pathways (RCP) are used and involves different activities for which high level climate change expertise is needed (see figure 6). There is a large body of scientific literature providing insight on how the climate is likely to change for different climate variables all over the world.

Effective climate change adaptation requires spatially and temporally downscaled climate projections. If resources allow and decision making requires climate projections for specific climate variables and location for which no projections are available yet, a tailored projection can be carried out by experts. They start from the identified climate variable and the regions delineated through the value chain mapping, and follow steps as illustrated in figure 6. 


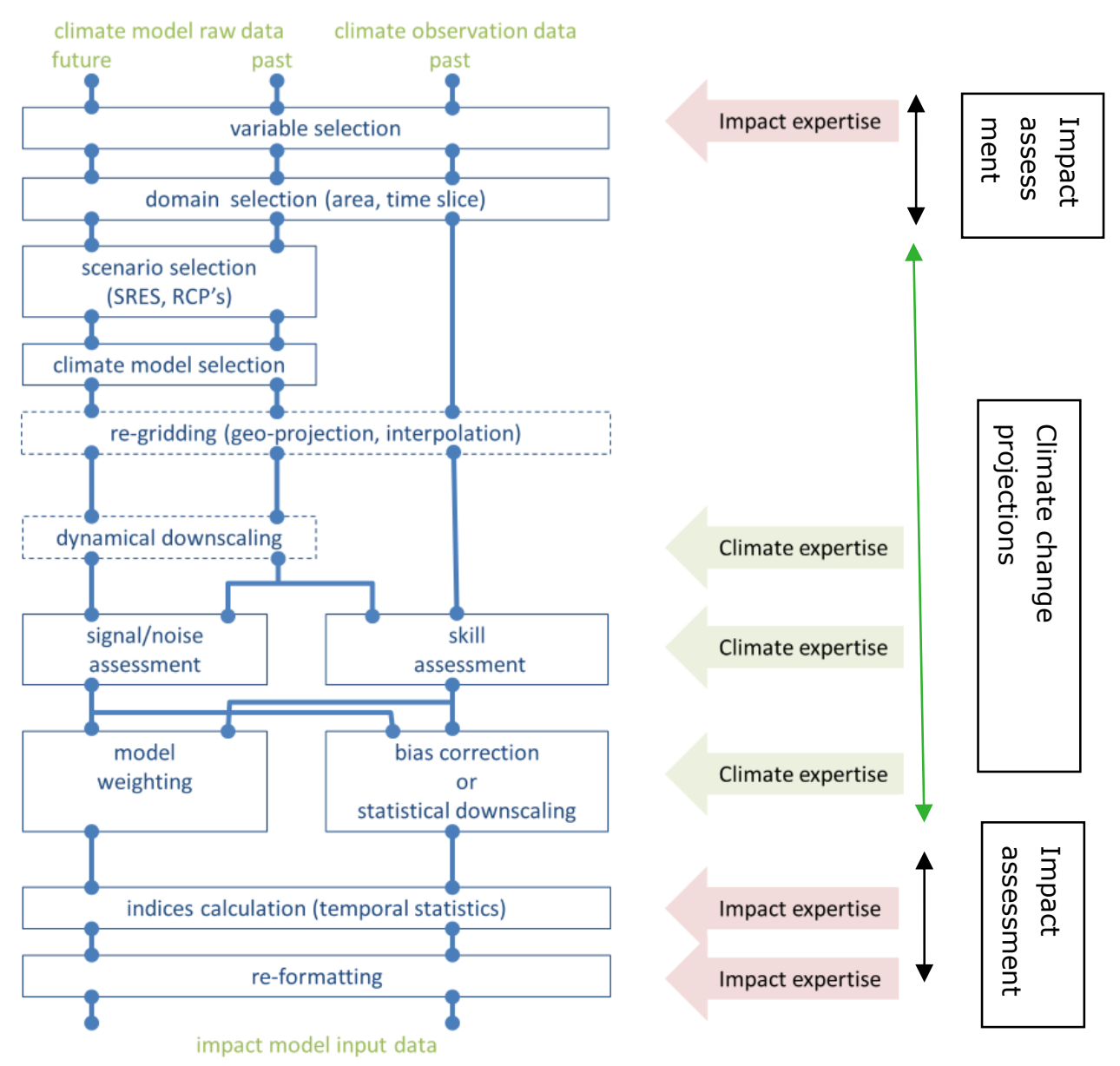

Figure 6. Climate data processing chain (adapted from Hutjes, 2011)

\section{Variable and Domain selection}

Depending on the research question, the area for which data is required, should be defined. (e.g. the Alps or the Iberian peninsula, or the city of London, etc), the time horizon that data is needed for (e.g. 2070-2100) and of course the necessary variable the impact model needs (e.g. temperature, precipitation, sea level pressure, etc.). We recommend for the area to not be too small; it generally should cover a number of grid cells of the chosen climate model, so for Global Climate Model (GCM) data on the order of $1,000,000 \mathrm{~km} 2$ or for RCM data about $10,000 \mathrm{~km} 2$. Similarly, the time slice should not be too narrow. To get a statistically representative period at least 30 years of data is required. Alternatively ensemble data may be used to increase the temporal sample.

\section{Scenario selection}

You need to make a choice which type of global development pathway your impact study will be placed in. You can choose from the different SRES scenarios or the different RCP scenarios (see Scenarios for more information).

\section{Model selection}

You need to make a choice which climate model will produce the data you need. That choice may depend on model skill, on sampling the spread in climate sensitivities, institutional preferences, etc.

\section{Re-gridding}

You may need to match the grid between the model data and the observed data or between data from different models. This may involve re-projection from e.g. a stereographic projection to a regular 
lat/lon grid, interpolation. Tools to do so are /will be provided on various climate portals (e.g. https://climate.copernicus.eu) or can be found and used offline, e.g. Climate Data Online (CDO) https://www.ncdc.noaa.gov/cdo-web/.

\section{(Dynamical) downscaling}

Climate model data are often of a too coarse resolution to make them directly useful in impact studies. You may need to downscale them. In dynamical downscaling you use a regional climate model to do so. This is not a task an impact researcher normally does. Instead you can use RCM data produced by others, e.g. from the CORDEX project.

\section{Skill assessment}

For each climate variable that you need in you impact model you need to assess any systematic biases generated by the GCM of your choice. You need climate data simulated for the past/present by the same model and compare them against observations. Your climate model data may be e.g. $2 \mathrm{~K}$ to warm, or producing $30 \%$ to low precipitation, in the region of your choice. The quality indicator you get in this way can be used either for model weighting (see below) or can be used to correct future data. (See Bias correction methods for more information).

Skill assessments for seasonal and decadal predictions differ from those for climate projections in two aspects. The first is that systematic biases are not constant in time, but generally increase with forecast time, due to model drift. The second is that since we are dealing with real forecasts, skill should also be quantified in terms of how often the forecast is right or wrong. This type of analysis is generally called verification.

\section{Model weighting}

Not all climate models perform equally well in reproducing (any aspect of) the current climate. When you create stochastic climate data you may combine data from various models and weigh each according to its skill. This is a complicated task (see e.g. Weigel, 2010), please ask advice from a climatologist with the relevant expertise (Contact the Expert) and more information will follow.

\section{Bias correction}

With systematic biases quantified you should now correct for these. In its simplest form you simply add or subtract a bias (delta correction, e.g. for temperature) or you add or subtract a relative bias (scaling, e.g. for precipitation), generally on a month-by-month, gridcel-by-gridcel basis. Much more complicated methods exist (see Bias correction methods for more information). Though the basics are simple, experience helps in the process, don't hesitate to ask advice (Contact the Expert). Statistical downscaling implicitly includes also a form of bias correction; so when you perform this type of downscaling (but NOT when you use dynamical downscaling results) you can skip bias correction as a separate processing step (see https://uls.climate.copernicus.eu/login for training resources on bias correction and downscaling).

For seasonal forecast, bias correction takes a slightly (but crucial!) different form in that biases not only vary by month, but also by forecast time. Otherwise the methods are similar.

\section{Indices calculation}

From these climate data you may finally need to calculate any indices (percentiles, averages, extremes indicators) as needed by your own impact model.

\section{Re-formatting}

The final climate data processed as above may need to be matched to the specific input format requirements of the impact model.

Due to required climate change knowledge and data processing skills, climate change projections are usually carried out by climate scientists. For a set of relevant climate variables bias-corrected regional climate projections will be developed and visualised. 


\section{Visualising climate change}

Visualisations can improve communication with actors about climate change and climate change projections and may increase people's understanding. Multiple visualisation methods exist. Figures 7, 8 and 9 provide examples of different ways of visualising.
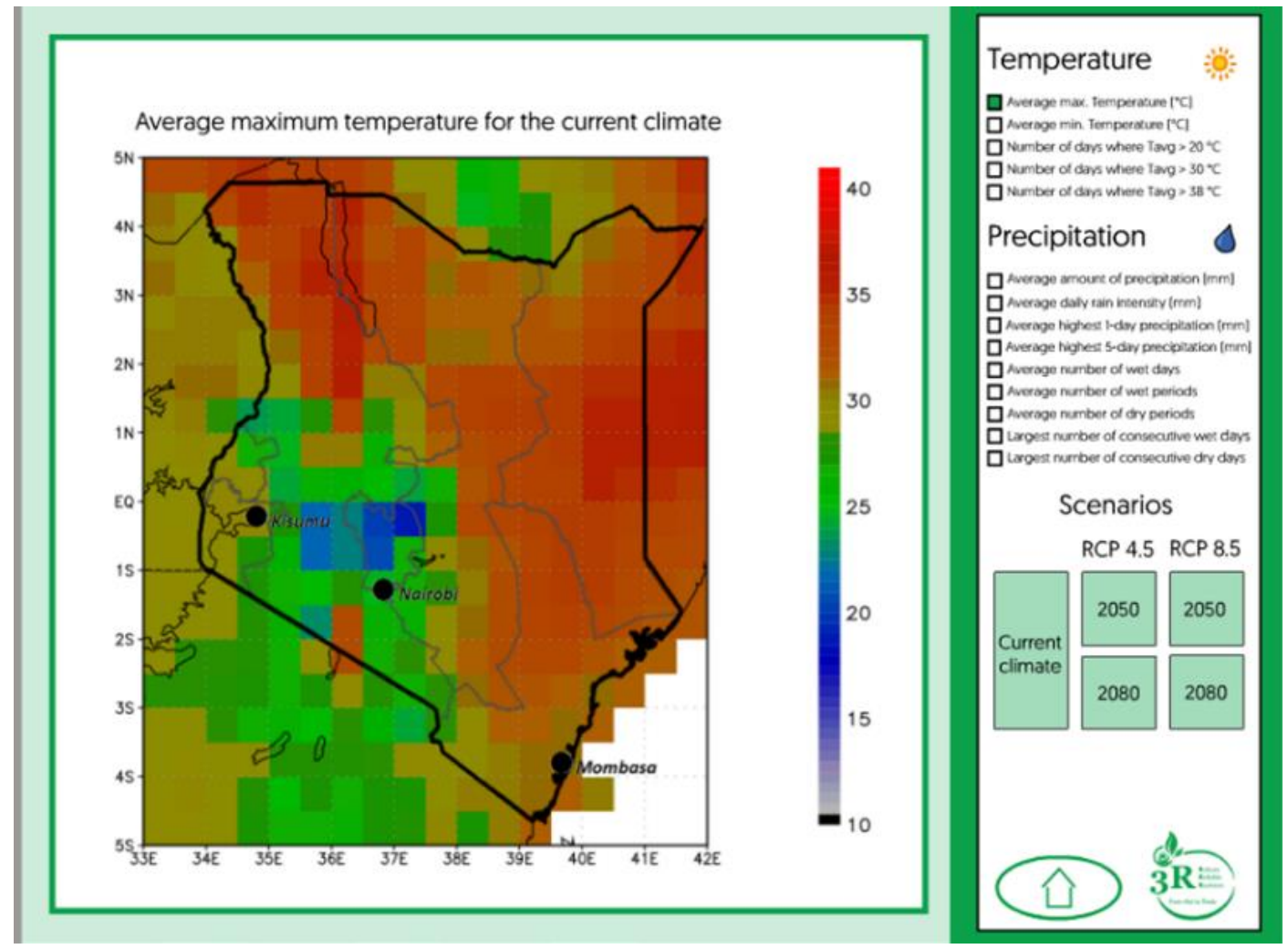

Figure 7: (Interactive) climate atlas for Kenya (in development, Goosen, 2018)

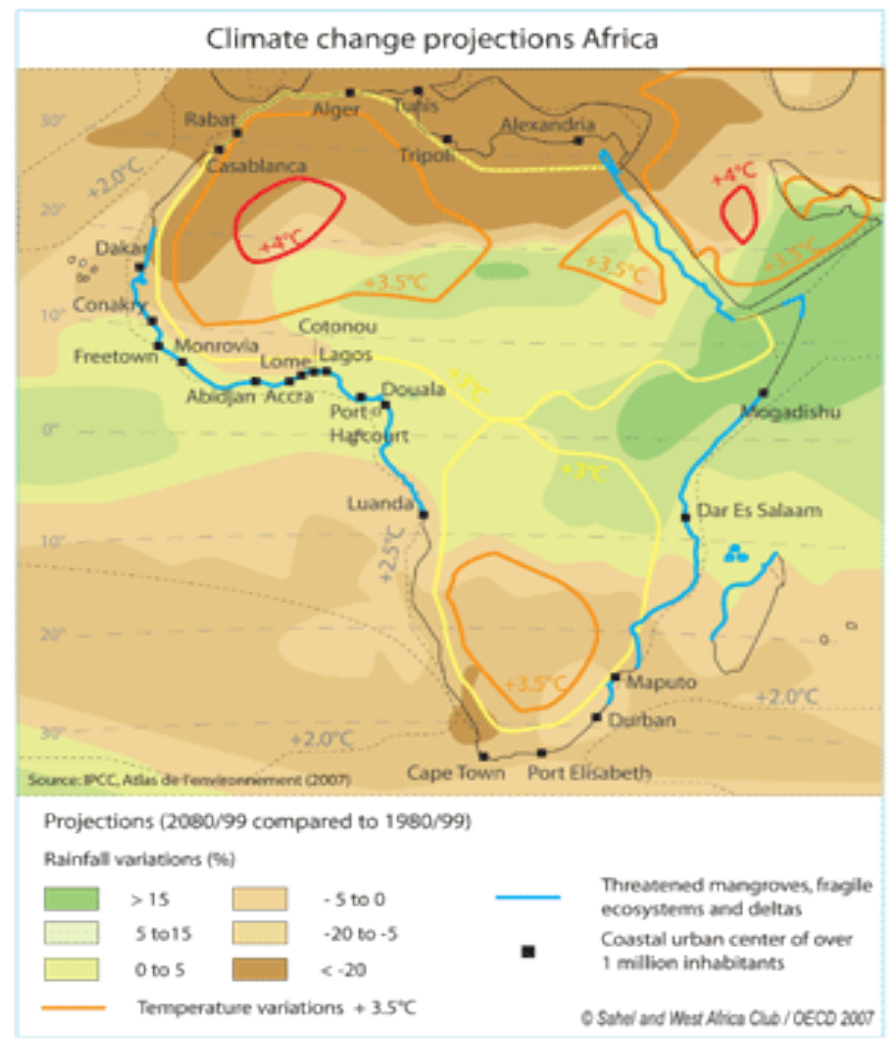

Figure 8: Climate change projections in Africa (OECD, 2007) 


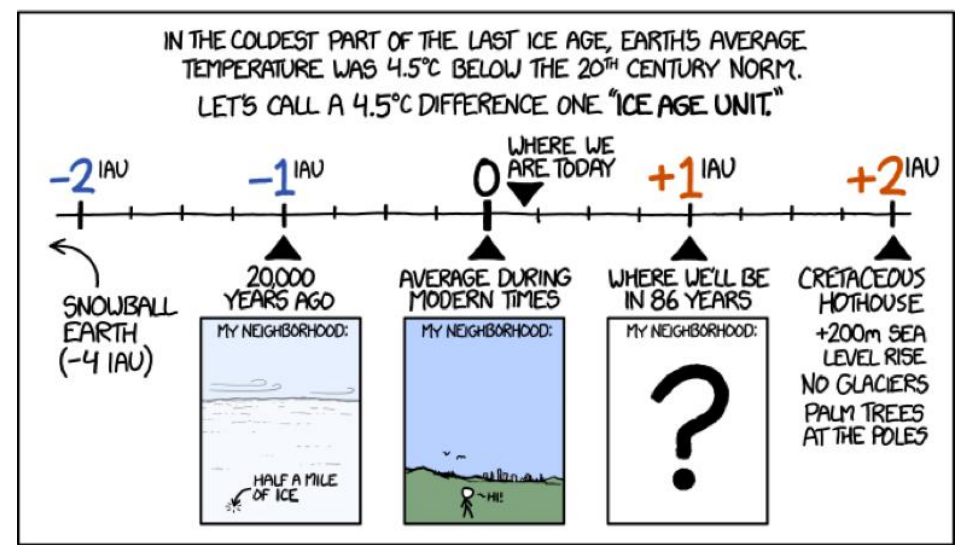

Figure 9: Cartoon on climate change (Climaterealityproject.org)

Experience shows that it is important to engage the users in selecting the best way to visualize climate change.

\subsection{Step 2 - Assessing impact climate change on water availability}

This step addresses the major question 'given the climate change projections how might actors' livelihood and/or business become affected by climate change?'. For the agro-food sector, this question specifically focusses on CC impact on crop production and on water resources. WENR's services use multiple approaches to assess the effect of CC on crop production and water availability such as the use of impact models or participatory impact modelling. Both approaches are highly informed by existing literature on CC impacts.

\section{Activities}

2.1 Quantitative impact assessment CC on water availability

2.2 Quantitative impact assessment on crop production

2.3 Participatory impact modelling

\section{Outputs}

Information (maps, graphs) showing impact of CC on water availability and crop production (long term and short term) including likely change in crop yield and cropping cycles, water-yield gaps maps

\section{Quantitative impact assessment on water availability}

Depending on your research question and spatial and temporal demand for information you must choose a hydrological model to use. Hydrological models typically work with reservoirs, predicting the outflow of each reservoir with storage-discharge relationships that are solved numerically. Depending on your questions you should select a model that is more suitable for your purpose, such as surface water runoff, nutrient transport or groundwater flow and depletion. Commonly used models include SWAT: a river basin scale model developed to quantify the impact of land management practices in large, complex watersheds; MODFLOW: to simulate the flow of groundwater through aquifers; MIKE SHE: an integrated hydrological modelling system for building and simulating surface water flow and 
groundwater flow; VIC: a grid-based macro-scale hydrological model that hat solves both the surface energy balance and water balance equations. Includes effects of reservoirs and extractions on river discharge; includes water quality with multiple pollutants. The hydrological model will probably need to be calibrated to give accurate predictions.

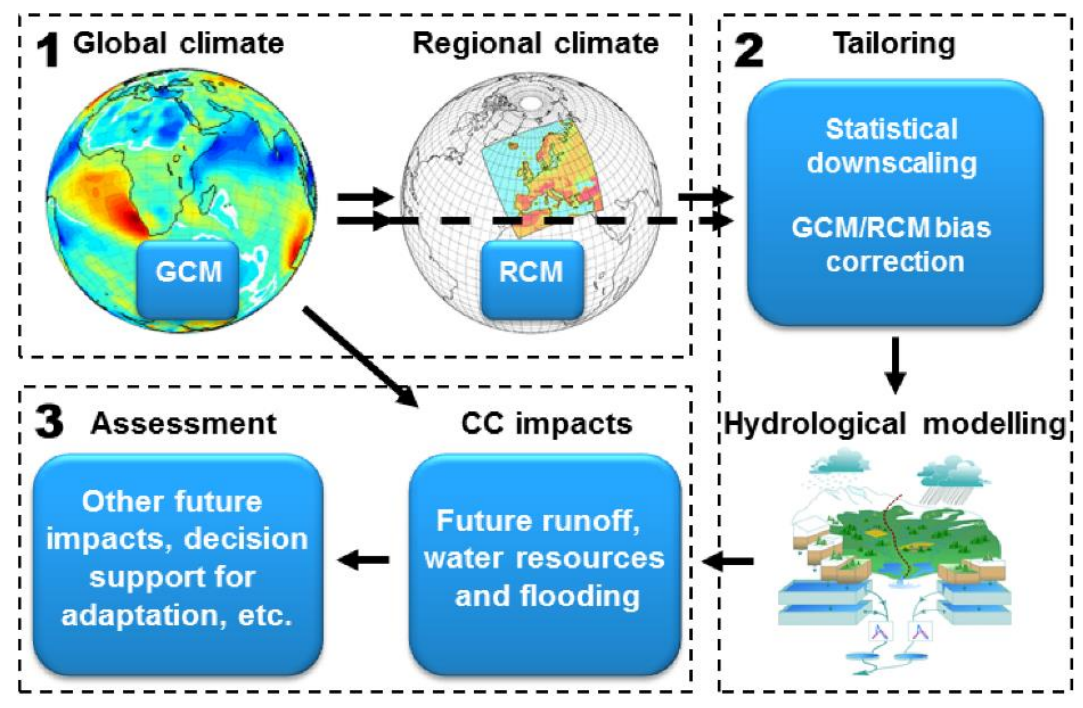

Figure 10: Flow hydrological modelling (Olsson et al.,2016)

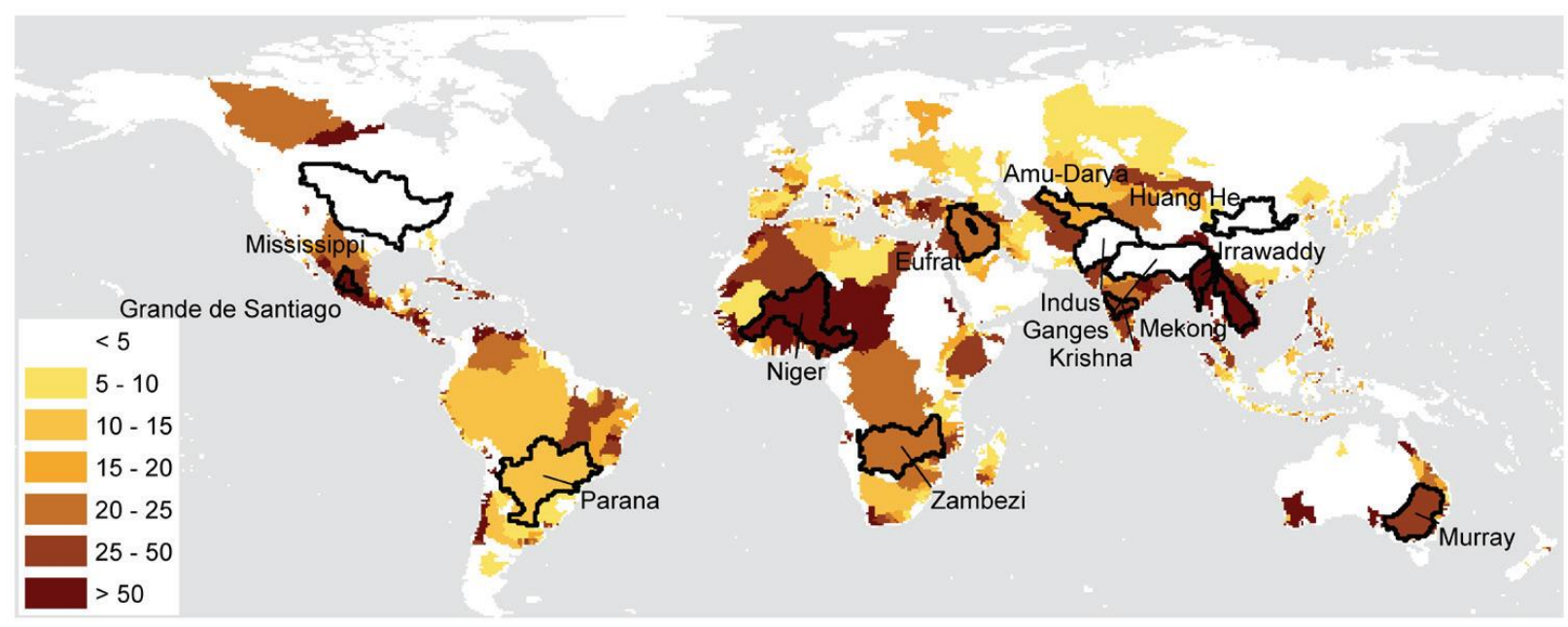

Figure 11: Distribution of the mean annual losses in irrigated crop production due to irrigation water shortage projected for the A2 scenario (in \% yr-1) (Biemans et al. 2012)

\section{Quantitative impact assessment on crop production}

Depending on your research question and spatial and temporal demand for information you must choose a crop model to use. A crop model typically describes processes of crop growth and development as a function of weather conditions, soil conditions, and crop management. Crop models can assist in preseason and in-season management decisions on cultural practices, fertilization, irrigation, and pesticide use. Crop models can assist policy makers by predicting soil erosion, leaching of agrichemicals, effects of climatic change, and large-area yield forecasts. Commonly used models include WOFOST: a simulation model for the quantitative analysis of the growth and production of annual field crops; APSIM: to simulate systems that cover a range of plant, animal, soil, climate and management interactions; CERES: a crop-environment resource synthesis models made for several 
crops; LPJml: dynamically determines potential natural vegetation, as well as agriculture and managed grasslands, and biomass for bioenergy plantations. It includes hydrology, including reservoirs for irrigation. The crop model will probably need to be calibrated to give accurate predictions.

\section{IMPACTS OF CLIMATE CHANGE}

By 2030, nine out of 10 of the major crops will experience reduced or stagnant growth rates, while average prices will increase dramatically as a result, at least in part, due to climate change.

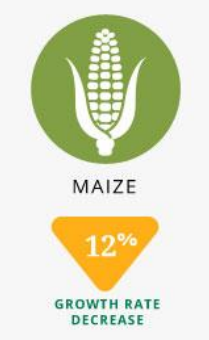

$$
\begin{array}{r}
90 \% \\
\text { PRICE } \\
\text { INCREASE }
\end{array}
$$

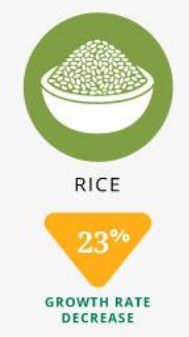

$89 \%$

PRICE
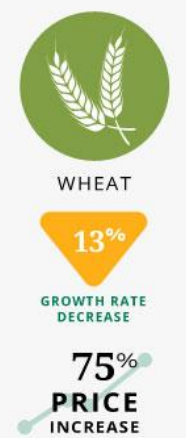

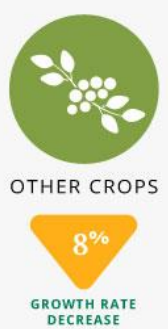

$83 \%$

PRICE

Figure 12: Farming First (https://farmingfirst.org/Post2015-Planet\#234321)

For those value chains for which a quantitative impact assessment will not be carried out use can be made of existing literature. Existing insights into the effect of climate change on available fresh water and crop production in combination with the regionalised climate change projections will be used as input for the discussions on climate risks in step 3.

Impact assessment results can be visualised in several ways. Figure 12 and 13 show just two examples. Figure 12 presents the impact of climate change on a few major crops. Figure 13 shows likely changes in cropping cycle due to climate change. It shows time to maturity (harvest) of soybean sown after winter-wheat harvesting. In 2010-2040 (top row) soybean is rarely ripe (yellow bar) before the first frosts (green line), while in 2070-2100 (bottom row) soybean always is harvestable before the first frosts.

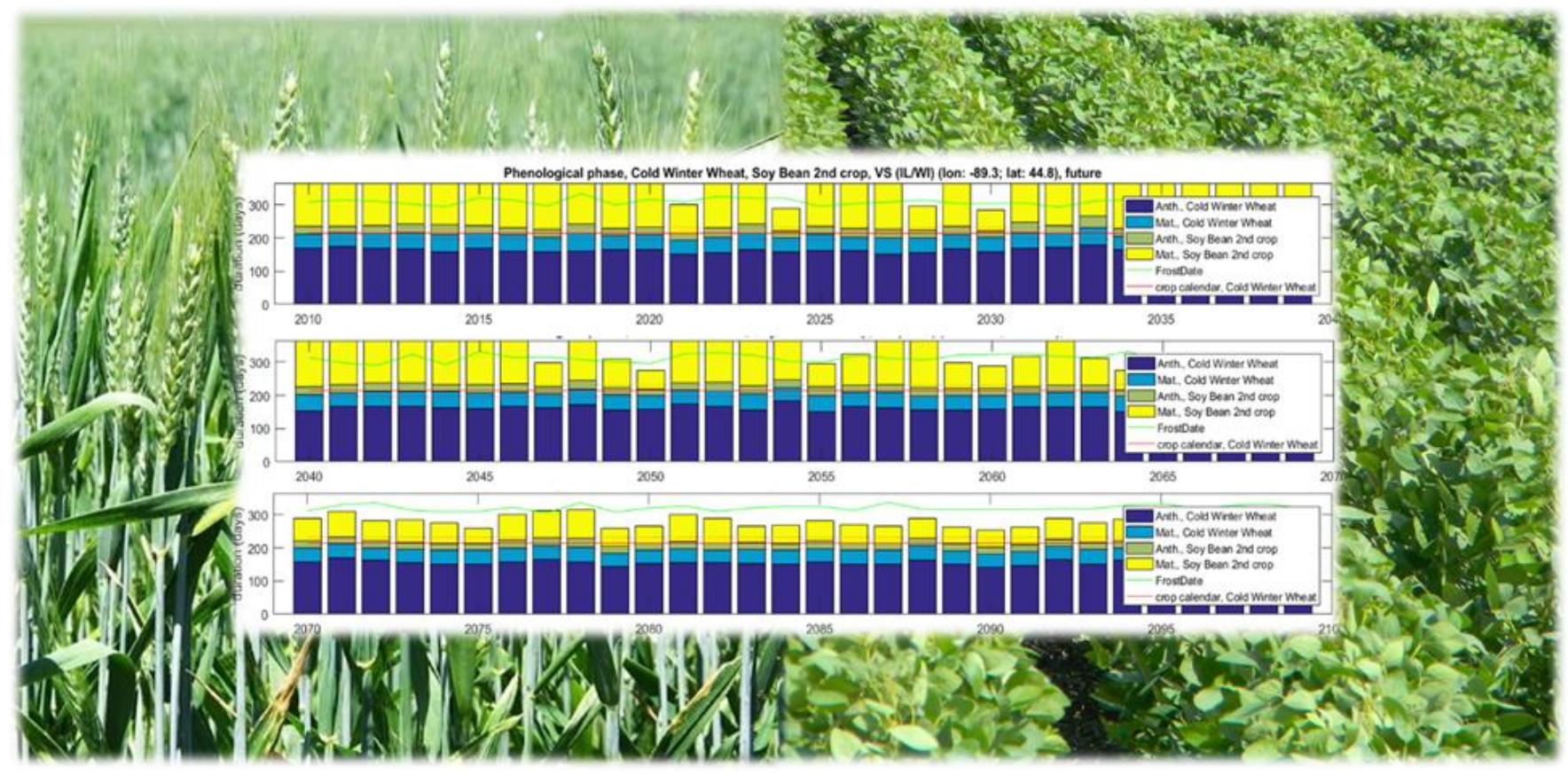

Figure 13: Demonstrating potential for winter-wheat and soybean double cropping in North America over coming century, using simple crop development rates, using GDD type climate indices

(Hutjes, 2017) 


\section{Participatory climate change impact modelling}

QUICKScan is a participatory impact modelling method that links stakeholder- and decision maker knowledge and preferences to available spatial and spatio-statistical data, and is designed for group use, in a multi-stakeholder workshop setting. QUICKScan was developed together with the European Commission in the early 2010's in their demand for an easy to handle research tool that is fast, simple and transparent, and that requires little data and can be carried out in a multi-actor setting (Verweij et al., 2016).

A QUICKScan within a climate risk assessment session explores alternative scenarios and their likely impacts by addressing the following issues: 1) scope of the societal and environmental aspects with respect to spatial ambitions or risks (e.g. make an inventory of likely climate change projections and population growth); 2) describe typical 'pictures' of the past, actual condition and trends (e.g. map the location of current cropping areas, current and future suitable cropping areas, or changing diets ); 3 ) identify the elements and interactions that are relevant for the persistence of these patterns, trends and impacts (e.g. urbanisation or intensification); 4) devise strategies and options to preserve, restore, use, improve, mitigate, or adapt (e.g. change crops or varieties, organise farmers, infrastructural works), and; 5) locate hotspot areas as targets for action (e.g. build water retention basins, or dykes).

Each QUICKScan session follows a number of logical phases: a scoping phase to formulate key questions of the workshop, workshop preparation to select participants and available data, the workshop itself and reporting on results and observations (figure 14).

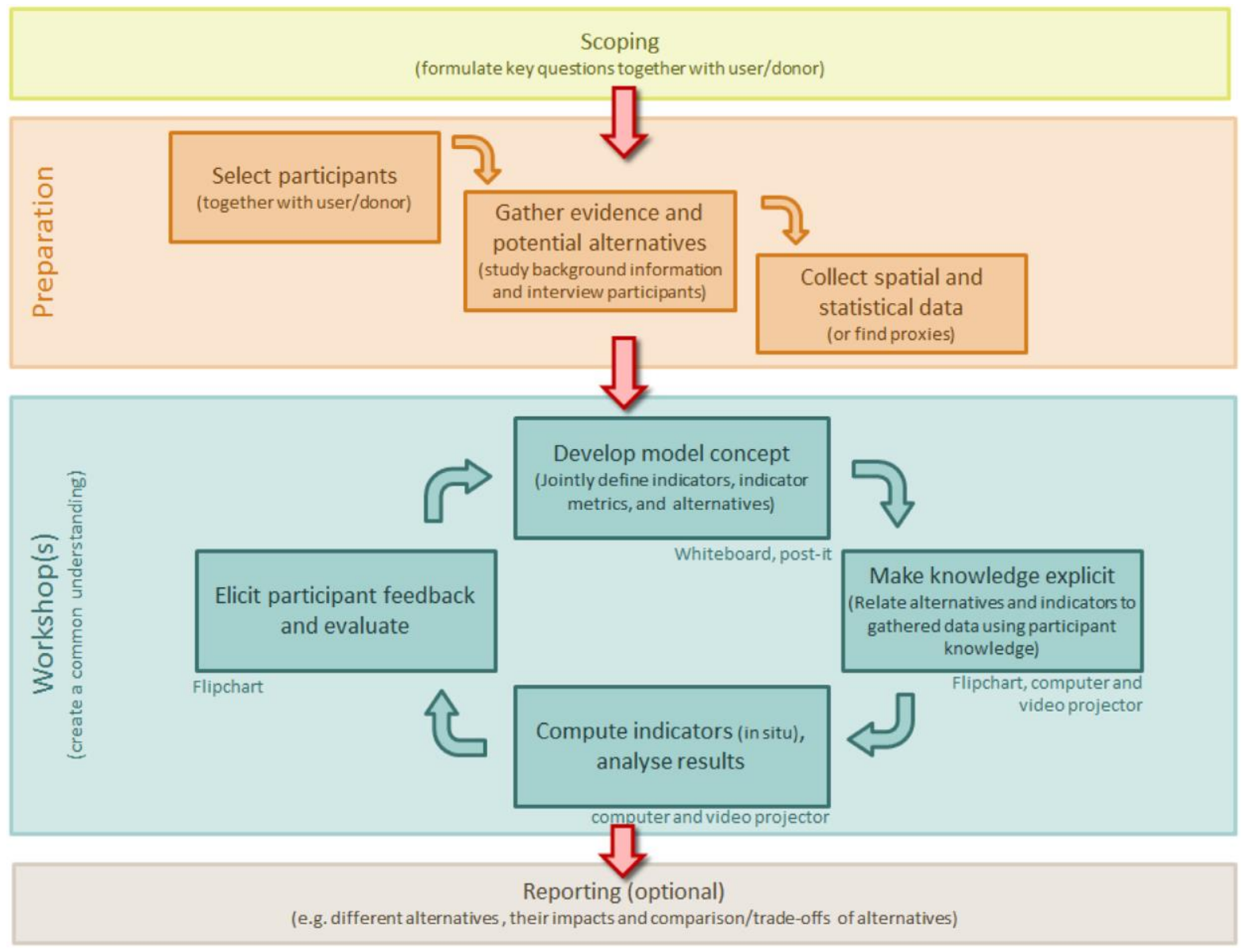

Figure 14: QUICKscan approach 
The following iterations of model conceptualisation are followed during the workshop:

- Develop a model concept-The participants jointly make an inventory of relevant indicators, indicator metrics and alternatives; or compare different stakeholder perspectives.

- Make stakeholder knowledge explicit-The participants relate indicator concepts to available data by building a causal chain of participants' knowledge.

- Compute the indicators-The tool operator calculates indicator maps and summary charts as requested by the participants (e.g. averages per neighbourhood, or trade-off of a number of indicators per administrative unit).

- Evaluate-the participants evaluate the performance of the indicators in a single alternative, or evaluate the performance of summaries of indicators across alternatives. The evaluation might trigger another iteration in which participants identify additional indicators, perspectives and refining knowledge.

\subsection{Step 3 - Climate Change risk assessment}

The third step identifies the risk that climate change poses to each of the actors' business in the value chain. Here climate risks are potentially severe adverse consequences for social ecological systems resulting from the interaction between climate-related hazards and vulnerability of people and systems exposed to these hazards. For the SNV project this step involves three major activities.

Given projections of future climate change and their impact on crop production and water availability the three major questions to address include: 1 ) what are the (potential) risks for people's livelihood and businesses of actors in the value chain, 2) what's actors' current adaptive capacity to address these risks, and 3) how do they prioritise the risks?

\section{Activities}

3.1 Assess (potential) risks on livelihood and/or business due to climate change induced changes in water availability and crop production (annex 5.4)

3.2 Assess current adaptive capacity to address risks (annex 5.4)

3.3 Prioritisation of risks (annex 5.5)

\section{Outputs}

- Identification (visualisation) of value chain elements (actors, activities, resources) at risk due to climate induced changes in crop production and water availability

- Insight into actors' perception of their capacity to mitigate adverse impact on their livelihood/business

\section{Survey / preparatory interviews}

If time allows, it is recommended to start off this activity with interviews with actors in the value chain. Actors' experience with consequences of changes in water availability and crop production for their business as well as the effectiveness of current adaptation strategies will serve as valuable input for the risk assessment workshop. Visuals showing changes in crop yield, cropping cycles, suitable areas, water-yield gaps should be used as input for the discussion.

Based on the interviews (step 3) and outcomes of step 1 and 2, including a literature scan, a factsheet can be prepared as input for the discussion in the workshop. Table 2 on the following page shows an example of such a factsheet for a potato value chain. 
Table 2: Example of a factsheet summarising the climate risk assessment for the potato value chain based

\begin{tabular}{|c|c|c|c|c|}
\hline Potato (Kenya) & & Cropping calenda & potato & \\
\hline $\begin{array}{l}\text { CC projections for } \\
\text { relevant climate } \\
\text { variables } \\
\text { / extreme weather } \\
\text { events }\end{array}$ & $\begin{array}{l}\text { Projected change for } \\
\text { e.g.: } \\
\text { Exceedance of } 10 \\
\text { consecutive days } \\
\text { without rain during } \\
\text { planting time }\end{array}$ & $\begin{array}{l}\text { Projected change for } \\
\text { e.g.: } \\
\text { Exceedance of } 15 \\
\text { consecutive days with } \\
\text { heavy rainfall }\end{array}$ & $\begin{array}{l}\text { Projected change for } \\
\text { e.g.: } \\
\text { Frost/ } X \text { number of } \\
\text { consecutive days with } \\
\text { night temperature } \\
\text { below } 0^{\circ} \mathrm{C}\end{array}$ & $\begin{array}{l}\text { Projected change for e.g.: } \\
\text { High air humidity after } \\
\text { harvesting }\end{array}$ \\
\hline $\begin{array}{l}\text { Effect on crop } \\
\text { production }\end{array}$ & $\begin{array}{l}\% \text { change or estimation } \\
\text { in yield } \\
\text { (high/medium/low) } \\
\text { Change in timing } \\
\text { and/or availability }\end{array}$ & 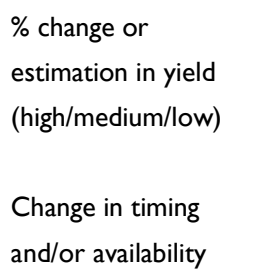 & $\begin{array}{l}\text { \% change or } \\
\text { estimation in yield } \\
\text { (high/medium/low) } \\
\text { Change in timing } \\
\text { and/or availability }\end{array}$ & $\begin{array}{l}\text { \% change or estimation } \\
\text { (high/medium/low) } \\
\text { Change in timing and/or } \\
\text { availability }\end{array}$ \\
\hline $\begin{array}{l}\text { Effect on water } \\
\text { availability }\end{array}$ & $\begin{array}{l}\text { \% change or estimation } \\
\text { (high/medium/low) }\end{array}$ & $\begin{array}{l}\text { \% change or } \\
\text { estimation } \\
\text { (high/medium/low) }\end{array}$ & $\begin{array}{l}\text { \% change or } \\
\text { estimation } \\
\text { (high/medium/low) }\end{array}$ & $\begin{array}{l}\text { \% change or estimation } \\
\text { (high/medium/low) }\end{array}$ \\
\hline $\begin{array}{l}\text { Impact for farmers } \\
\text { (diff. Gender and age) }\end{array}$ & $\begin{array}{l}\text { High/medium/low } \\
\text { Estimation of losses } \\
\text { (yield, income) }\end{array}$ & $\begin{array}{l}\text { High/medium/low } \\
\text { Estimation of losses } \\
\text { (yield, income) }\end{array}$ & $\begin{array}{l}\text { High/medium/low } \\
\text { Estimation of losses } \\
\text { (yield, income) }\end{array}$ & $\begin{array}{l}\text { High/medium/low } \\
\text { Estimation of losses } \\
\text { (yield, income) }\end{array}$ \\
\hline $\begin{array}{l}\text { Impact for input } \\
\text { suppliers (diff. Gender } \\
\text { and age) }\end{array}$ & $\begin{array}{l}\text { High/medium/low } \\
\text { Estimation of losses } \\
\text { (income) }\end{array}$ & $\begin{array}{l}\text { High/medium/low } \\
\text { Estimation of losses } \\
\text { (income) }\end{array}$ & $\begin{array}{l}\text { High/medium/low } \\
\text { Estimation of losses } \\
\text { (income) }\end{array}$ & $\begin{array}{l}\text { High/medium/low } \\
\text { Estimation of losses } \\
\text { (income) }\end{array}$ \\
\hline $\begin{array}{c}\text { Impact for traders } \\
\text { (diff. Gender and age) }\end{array}$ & $\begin{array}{l}\text { High/medium/low } \\
\text { Estimation of losses } \\
\text { (income) }\end{array}$ & $\begin{array}{l}\text { High/medium/low } \\
\text { Estimation of losses } \\
\text { (income) }\end{array}$ & $\begin{array}{l}\text { High/medium/low } \\
\text { Estimation of losses } \\
\text { (income) }\end{array}$ & $\begin{array}{l}\text { High/medium/low } \\
\text { Estimation of losses } \\
\text { (income) }\end{array}$ \\
\hline $\begin{array}{l}\text { Impact for processing } \\
\text { industry (diff. Gender } \\
\text { and age) }\end{array}$ & $\begin{array}{l}\text { High/medium/low } \\
\text { Estimation of losses } \\
\text { (income) }\end{array}$ & $\begin{array}{l}\text { High/medium/low } \\
\text { Estimation of losses } \\
\text { (income) }\end{array}$ & $\begin{array}{l}\text { High/medium/low } \\
\text { Estimation of losses } \\
\text { (income) }\end{array}$ & $\begin{array}{l}\text { High/medium/low } \\
\text { Estimation of losses } \\
\text { (income) }\end{array}$ \\
\hline $\begin{array}{c}\text { Impact for retails } \\
\text { (diff. Gender and age) }\end{array}$ & $\begin{array}{l}\text { High/medium/low } \\
\text { Estimation of losses } \\
\text { (income) }\end{array}$ & $\begin{array}{l}\text { High/medium/low } \\
\text { Estimation of losses } \\
\text { (income) }\end{array}$ & $\begin{array}{l}\text { High/medium/low } \\
\text { Estimation of losses } \\
\text { (income) }\end{array}$ & $\begin{array}{l}\text { High/medium/low } \\
\text { Estimation of losses } \\
\text { (income) }\end{array}$ \\
\hline Others & $\begin{array}{l}\text { High/medium/low } \\
\text { Estimation of losses } \\
\text { (income) }\end{array}$ & $\begin{array}{l}\text { High/medium/low } \\
\text { Estimation of losses } \\
\text { (income) }\end{array}$ & $\begin{array}{l}\text { High/medium/low } \\
\text { Estimation of losses } \\
\text { (income) }\end{array}$ & $\begin{array}{l}\text { High/medium/low } \\
\text { Estimation of losses } \\
\text { (income) }\end{array}$ \\
\hline
\end{tabular}




\section{Assess potential risks, current adaptive capacity and prioritise risks}

These three activities will be addressed in a one day workshop. In a one day workshop with value chain actors and other experts (climate, crop, trade), the participants will:

- Cross check and complement preliminary findings on impacts on their businesses due to climate change induced changes in water availability and crop production.

- $\quad$ Cross check and complement preliminary findings on adaptation strategies in use.

- Assess the effectiveness of current adaption strategies in view of climate change projections (step 1) and identify potential climate /weather related risks.

- Assess the likelihood and impact of potential risks to define and prioritise risks.

- Ensure women and youth participation (at least 30\% women, 30\% below 35) and enable their participation (support their voices, and emphasise on their inputs.

The results of this workshop can be documented in a table such as table 3 :

Table 3: Assessment of effectiveness of current adaption strategies to address climate change impacts and identification of potential climate/weather related risks

\begin{tabular}{|c|c|c|c|c|}
\hline $\begin{array}{l}\text { Value chain } \\
\text { Actors } \\
\text { (distinguish } \\
\text { gender / age) }\end{array}$ & $\begin{array}{l}\text { Impact due to climate induced } \\
\text { changes in water availability and } \\
\text { crop production }\end{array}$ & $\begin{array}{l}\text { Adaptation } \\
\text { strategies in use }\end{array}$ & $\begin{array}{l}\text { Adaptive } \\
\text { capacity score: } \\
\text { Hardly } \\
\text { effective (I)- } \\
\text { highly effective } \\
(5) *\end{array}$ & $\begin{array}{l}\text { Potential } \\
\text { climate - } \\
\text { weather } \\
\text { related risk } \\
\text { (yes /no) }\end{array}$ \\
\hline Male farmer, 25 & $\begin{array}{l}\text { Crop failure due to droughts during } \\
\text { germination (e.g. > more than } 10 \\
\text { consecutive days without rain) }\end{array}$ & $\begin{array}{l}\text { Drought resistant seeds, } \\
\text { but expensive and } \\
\text { difficult to access }\end{array}$ & 2 & Yes \\
\hline $\begin{array}{l}\text { Female farmer, } \\
42\end{array}$ & $\begin{array}{l}\text { Crop failure due to droughts during } \\
\text { germination (e.g. > more than } 10 \\
\text { consecutive days without rain). } \\
\text { Improper link to input supplier. }\end{array}$ & $\begin{array}{l}\text { Drought resistant seeds, } \\
\text { but expensive and } \\
\text { difficult to access }\end{array}$ & I & Yes \\
\hline $\begin{array}{l}\text { Female Input } \\
\text { supplier, } 33\end{array}$ & $\begin{array}{l}\text { Transportation of inputs not possible } \\
\text { due to heavy rainfall and landslides } \\
\text { (e.g. > more than } 10 \text { consecutive days } \\
\text { with heavy rain) }\end{array}$ & Early delivery of inputs & 4 & No \\
\hline Male Trader, 35 & $\begin{array}{l}\text { Transportation of yield not possible } \\
\text { due to heavy rainfall and land slides }\end{array}$ & $\begin{array}{l}\text { Purchase products from } \\
\text { other regions }\end{array}$ & 2 & Yes \\
\hline $\begin{array}{l}\text { Female } \\
\text { Processor, } 44\end{array}$ & $\begin{array}{l}\text { Insecure /decrease in supply of raw } \\
\text { materials }\end{array}$ & $\begin{array}{l}\text { Purchase products from } \\
\text { other regions }\end{array}$ & 2 & Yes \\
\hline Male Buyer, 50 & $\begin{array}{l}\text { Insecure /decrease in supply of } \\
\text { products }\end{array}$ & $\begin{array}{l}\text { Purchase products from } \\
\text { other regions }\end{array}$ & 2 & Yes \\
\hline
\end{tabular}

* Potential climate risk if adaptive capacity is $<3$

\section{Assess current adaptive capacity to address climate change impacts}

In the workshop, participants cross check, complement and further elaborate the interview findings on the impact on actors' livelihood and/or business due to climate induced changes in water availability and crop production. They further discuss current adaptation strategies and score their adaptive capacity to mitigate climate change impacts now and in future. The tool, including which questions to ask and how to rank them, can be found in annex 5.5. An additional tool that could be used to assess 
adaptive capacity is the 'resilience score card' (see table 4). This tool is often used in SNV's climate risk assessments and examines different dimensions contributing to value chain actors' resilience to climate change. A more detailed description on the score card is provided in Annex 3.

Table 4 : Example of a resilience score card (Source SNV, 2018)

\begin{tabular}{|c|c|c|c|}
\hline & low & high & \\
\hline -Awareness on climate change & & & $\begin{array}{l}\text { Awareness on the changes in weather patterns and } \\
\text { the effect on their business }\end{array}$ \\
\hline - Knowledge on climate change & & & $\begin{array}{l}\text { They would like to receive more knowledge on how } \\
\text { they can address CC in their operations. }\end{array}$ \\
\hline $\begin{array}{l}\text {-Access to information on } \\
\text { climate change }\end{array}$ & & & $\begin{array}{l}\text { They don't access information. Weather forecasts } \\
\text { regarded as unreliable. }\end{array}$ \\
\hline - Coping strategy in place & & & $\begin{array}{l}\text { Sourcing from other areas and other groups, } \\
\text { adjusting price. }\end{array}$ \\
\hline $\begin{array}{l}\text { Offering of climate-smart } \\
\text { products/services }\end{array}$ & & & $\begin{array}{l}\text { Sell silos and water pumps, stimulate farmers to use } \\
\text { drought-tolerant/early maturing seeds }\end{array}$ \\
\hline $\begin{array}{l}\text { - Future plans/ideas on how to } \\
\text { adapt }\end{array}$ & & & $\begin{array}{l}\text { Plans to distribute tree seedlings, help farmers to } \\
\text { purchase resilient inputs, compensate loss inputs }\end{array}$ \\
\hline Overall & & & \\
\hline
\end{tabular}

Identify and prioritise climate /weather related risks

In the next step these potential risks are further assessed in terms of likelihood of occurrence and impact on actors' business. Insight into impact and likelihood will be the basis for further prioritising risks. For this activity it is useful to invite some regional experts with knowledge about the crop and value chain under study, as well as gender experts. Regionalised climate change projection knowledge/insight needs to be available as well. Three columns can be added to the previous table to fill in the impact of risks and the likelihood of occurrence, and setting priorities or a new table can be used to document the results. Table 5 shows an example of such a table.

Table 5: Example of an identification and prioritisation of climate /weather related risks

\begin{tabular}{|c|c|c|c|c|}
\hline $\begin{array}{l}\text { Value chain } \\
\text { Actors } \\
\text { (distinguish } \\
\text { gender / } \\
\text { age) }\end{array}$ & $\begin{array}{l}\text { Impact due to climate } \\
\text { induced changes in water } \\
\text { availability and crop } \\
\text { production }\end{array}$ & $\begin{array}{l}\text { Consequence of } \\
\text { impact (insignificant, } \\
\text { minor, moderate, } \\
\text { major, catastrophic) }\end{array}$ & $\begin{array}{l}\text { Likelihood of } \\
\text { occurrence (very } \\
\text { low, low, moderate, } \\
\text { high, very high) }\end{array}$ & $\begin{array}{l}\text { Prioritised } \\
\text { risks }\end{array}$ \\
\hline Farmers & $\begin{array}{l}\text { Crop failure due to droughts } \\
\text { during germination (e.g. }> \\
\text { more than } 10 \text { consecutive } \\
\text { days without rain) }\end{array}$ & $\begin{array}{l}\text { Actors' assessment }+ \\
\text { Assessment of experts }\end{array}$ & $\begin{array}{l}\text { Actors' assessment } \\
+ \text { assessment of } \\
\text { climate experts }\end{array}$ & \\
\hline Traders & $\begin{array}{l}\text { Transportation of yield not } \\
\text { possible due to heavy rainfall } \\
\text { and landslides (e.g. > more } \\
\text { than } 10 \text { consecutive days with } \\
\text { heavy rain) }\end{array}$ & & & \\
\hline Processor & $\begin{array}{l}\text { Insecure /decrease in supply } \\
\text { of raw materials }\end{array}$ & & & \\
\hline Buyers & $\begin{array}{l}\text { Insecure /decrease in supply } \\
\text { of products }\end{array}$ & & & \\
\hline
\end{tabular}




\subsection{Step 4 - Identification of potential business case}

The activities under this step will be part of the second day of the workshop with actors of a value chain.

\section{Activities}

4.1 Identification of potential adaptation strategies addressing climate risk

4.2 Identify potential business ideas

4.3 Further explore potential business ideas

\section{Outputs}

Matrix showing potential adaptation strategies and business ideas

\section{Exploring adaptation strategies and identify potential business ideas}

After the actors have discussed and prioritised the climate risks on the first day of the workshop, on the second day an inventory will be made of potential adaptation strategies. The number of strategies can be further completed by a list prepared in advance by experts.

The following elements will be part of the identification;

- Prioritised climate-weather related risk in the context of the value chain

- Possible adaptation strategy to address the prioritised risk

- How do actors' (women and men of different age groups) perceive the feasibility - sustainability (soc. fin, cultural, tech) - is the strategy gender and age inclusive or is it necessary to develop specific strategies towards women, youth and/or other vulnerable groups?

- Is there any actor (in the value chain or elsewhere) who could be interested to transform the adaptation strategy into a business?

- $\quad$ Are there any customers who are willing/able to pay for the service /product being sold?

- Do we consider this adaptation strategy as a potential business idea? Yes/No

Table 6 shows aspects to consider when identifying feasible and climate smart business ideas that address climate related risks.

Table 6: Defining feasible and climate smart business ideas

\begin{tabular}{|c|c|c|c|c|}
\hline $\begin{array}{l}\text { Value chain } \\
\text { actors }\end{array}$ & $\begin{array}{l}\text { Prioritised climate - } \\
\text { weather related risk }\end{array}$ & $\begin{array}{l}\text { Possible } \\
\text { adaptation } \\
\text { strategy }\end{array}$ & $\begin{array}{l}\text { Feasibility - } \\
\text { sustainability } \\
\text { (soc. fin, } \\
\text { cultural, tech) } \\
\text { /scalability }\end{array}$ & $\begin{array}{l}\text { Business idea? } \\
\text { Business owner, } \\
\text { clients, value } \\
\text { proposition? }\end{array}$ \\
\hline Farmers & $\begin{array}{l}\text { Frequent droughts } \\
\text { during germination } \\
\text { significantly } \\
\text { reducing crop yield } \\
\text { Frequent heavy } \\
\text { rains causing } \\
\text { water logging and } \\
\text { tuber rot }\end{array}$ & $\begin{array}{l}\text { Drought resistant } \\
\text { seed potato }\end{array}$ & Moderate & $\begin{array}{l}\text { Drought resistant } \\
\text { seed potato } \\
\text { Seed company } \\
\text { (ENZA seeds) }\end{array}$ \\
\hline $\begin{array}{l}\text { Input supplier } \\
\text { (specify per type) }\end{array}$ & Etc. & & & \\
\hline
\end{tabular}


Adaptation strategies may differ greatly and depend on the context. Other examples of adaptation strategies are shown in Box 1 (SNV, 2018)

Box 1 - Examples of adaptation strategies to mitigate CC risks in value chains (Source : SNV, 2018)

- Diversification

- $\quad$ Storage \& Preservation

- Off-season production / Incomes

- Integrated soil fertility management

- Integrated pest management

- Efficient water use and conservation

- Landscape level plans

- Agroforestry

- Public private partnerships

- Innovative finance (e.g. climate risk insurance)

- Sustainable \& participatory rangeland management

- Inclusive business

- Governance \& market system development for climate-smart agriculture

- Climate-smart soil \& crop management

- Improved seeds \& seed supply systems

- Climate information systems

- Renewable enerqy solutions

\section{Further explore potential business ideas}

In this last step the identified adaption strategies as identified in the previous step are further explored to find out if some of them can be considered a business idea. Some adaptation strategies will have the potential to become a business case, others will not. In order to assess the business value of such adaptation strategies, the first scoping will entail the following questions:

- Does the adaptation strategy decrease cost?

- Does the adaptation strategy increase profit?

- Does the adaptation strategy decrease risk?

These questions determine the extent to which a value proposition can be made, which forms the heart of the business model canvas, a communication tool to describe a business model. Another way to describe this in a less static way is to describe, preferably in one sentence what this adaptation strategy would mean to the receiver/person buying it. The Business Model Canvas (BMC) is a handy framework to describe how a company /firm creates value, relates to its customers and generates revenue from a set of operations. It combines several elements into a coherent mix that is considered to be essential for a business, see figure 12 : 


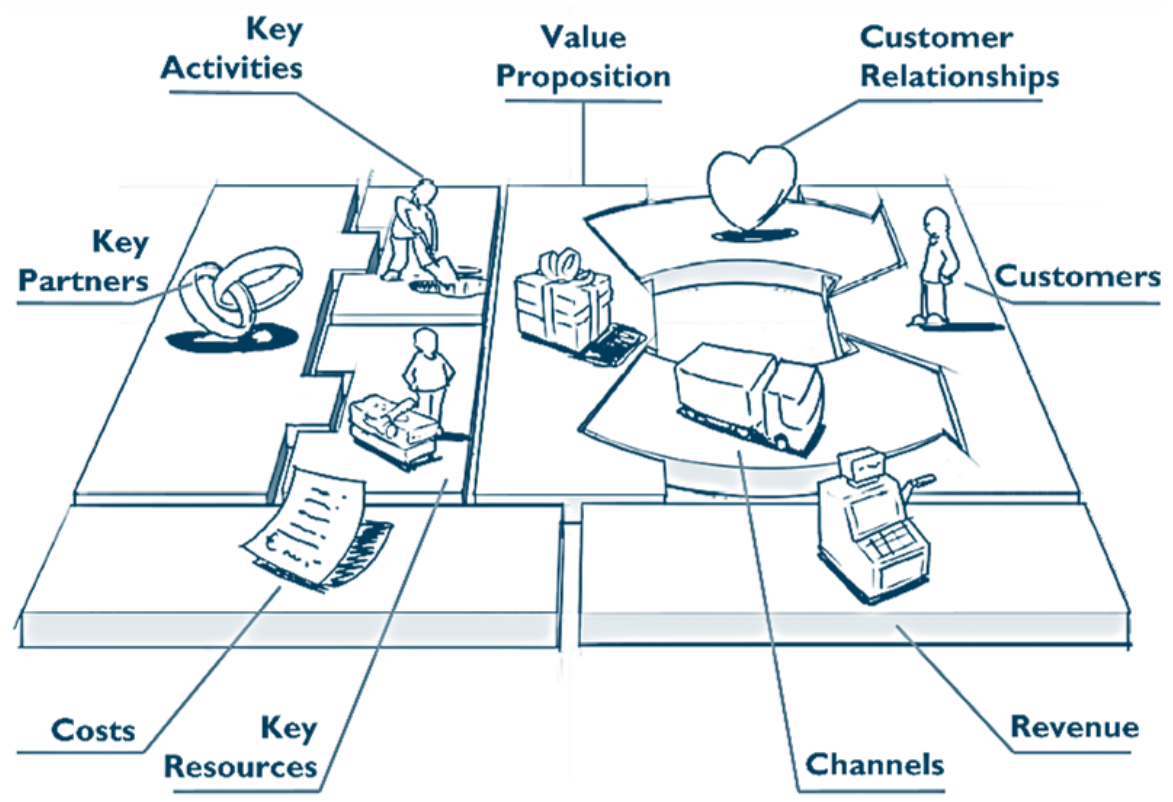

Figure 12 Business Model Canvas

As all business ideas should be part of a climate smart goal and have positive social and environmental impact, we have created a specific canvas for the CSA-EA project, see figure 13.

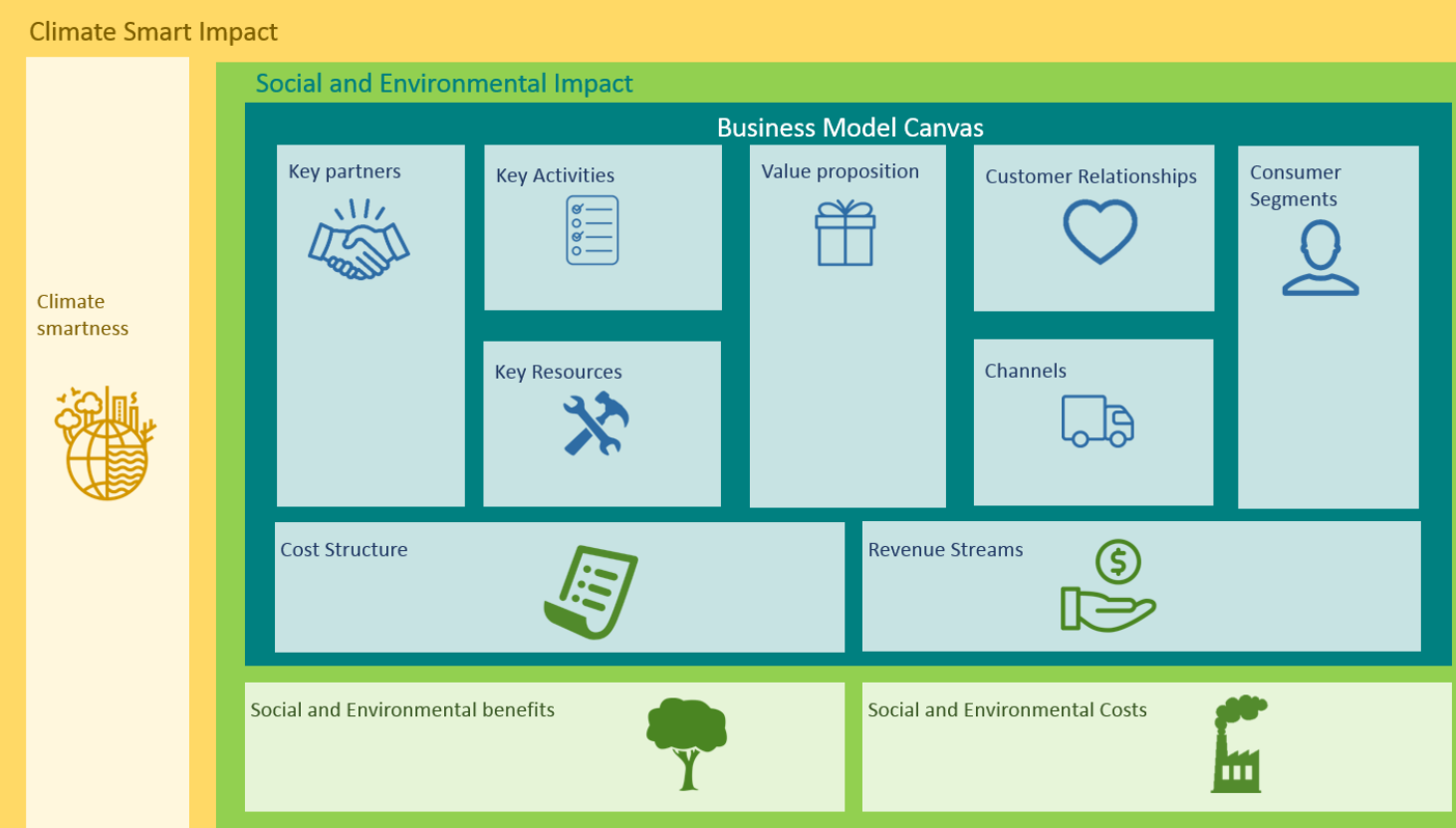

Figure 13 Climate Smart Business Model Canvas

During the workshop, key stakeholders can make use of such a Canvas to further structure their ideas. The outer (yellow) canvas should describe ways in which the idea contributes to climate smartness, this can done by relating to the three pillars of climate smart agriculture for example: 

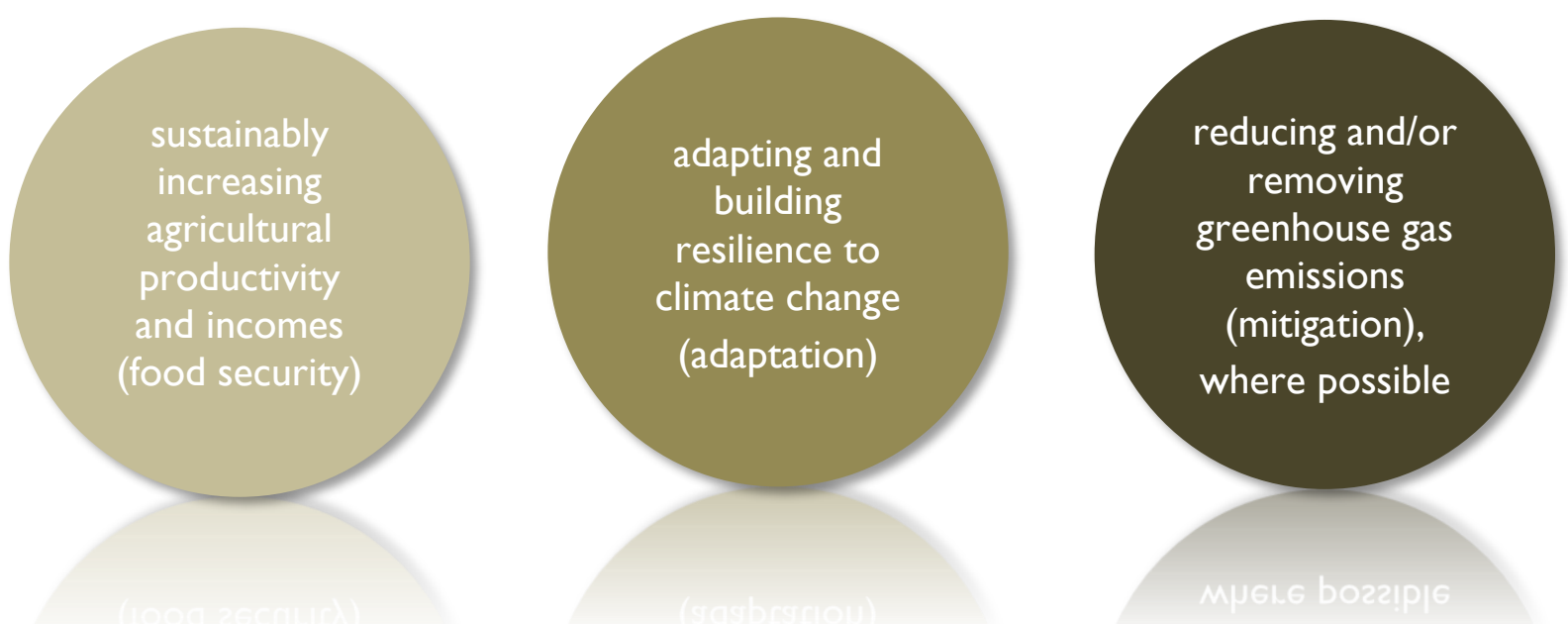

The middle canvas relates to social and environmental costs and benefits the idea might have. The inner conventional Business Model Canvas exists of nine different parts and it does not matter all that much where you start, although the value proposition in the centre offers the heart of the canvas and can as such be considered the most important element. The following questions can help them think along:

\section{Key partners}

- Who are your partners and suppliers for this idea? (make gender and age specific)

- Which core activities do they undertake?

- What sources will you need to execute your idea?

\section{Key activities}

- What are the core activities of your plan?

- What will you due to earn money with this idea?

\section{Key resources}

- What will you need to start with this plan?

- What are the different components of your product or idea?

\section{Value Proposition}

- What value are you offering your customer? (make gender and age specific)

- What problem are you solving?

- Which need are you fulfilling?

- What bundle of products are you delivering to what sort of customer (customer segment)?

- How do women and youth access the product and benefit from the service?

\section{Customer Relationship}

- What sort of relationship are landowners expecting of you?

- $\quad$ How are these relations fitting with your business model? Is it nicely integrated?

- How expensive is it to maintain these relationships?

\section{Channels}

- What channels would your customer prefer to be reached through? (make gender and age specific)

- How do you get to your client?

- Which channel is the most cost efficient?

- How are your channels integrated, what works best?

\section{Customer segment}

- Who are you creating value for?

- Who are your most valued customers? 


\section{Cost structure}

- What are the most important costs of this idea?

- Which resources and activities are most expensive?

\section{Revenue}

- Which value are your customers prepared to pay for?

- What are they paying for at this moment?

- How are they paying and how would they prefer to pay?

\section{Social and Environmental Costs}

- Does it exclude specific social groups?

- Does it exclude specific age groups?

- Does it emit greenhouse gases?

- Does it require additional fuel/electricity?

- Does it generate noise?

Social and Environmental Benefits

- Does it pay specific attention to women?

- Does it pay specific attention to youth?

- Does it reach people in areas that are often not included?

- Does it improve water quality/quantity?

- Does it improve air quality?

- Does it improve soil quality? 


\section{$3 \quad$ Market potentials and clients}

\section{Market potentials}

Recognizing the problem, identifying climate related risks in the supply chain and responding with adaptation measures can help agri-food businesses to minimize their risks and strengthen resilience. Responding to the effects of climate change will also provide opportunities for innovative climate resilient products and services and new markets.

There are different climate risk assessment tools on the market (IFAD, Acclimatise, GIZ, see Section 1.4). The added value of WENR's climate risk assessment services is that the service is based on state of the art scientific knowledge (climate - water - food models, cost benefit assessments of climate impact - climate adaptation measures) in combination with client-oriented and well facilitated advisory processes.

The climate risk assessment services target the agri-food sector, and has a strong market potential in the following market segments: crop producers, food manufacturers and food \& beverage retailers. The service aids market actors, which are part of the agricultural supply chains, in understanding the likely impact of climate change and variability on their direct business, and possible adaptation strategies that mitigate climate related risks, which are cost effective and/or increase their business opportunities.

\section{Potential clients}

The Climate Risk Assessment Services target (actors in) agricultural supply chains and agri-food networks whose business and/or livelihood heavily relies on water.

Targeted agri-food networks and companies include:

- Agri-food networks, e.g. FNLI

- Sustainable Agriculture Initiative Platform

- (International) agri-food companies, e.g. Unilever, Coca Cola, Vernof, Heineken

- Farmer organisations such as the International Farmer Organisation

- Financial institutions, e.g. FMO

- Irrigation consortia

- Commodity trading companies

- $\quad$ Seed companies (e.g. ENZA zaden, BASF)

- Supply chains (food), e.g. edible oils and fats, soya, sunflower, sesame, wheat, sugar cane

Other interested clients include:

- $\quad$ NGOs (e.g. Red Cross, HIVOS, OXFAM NOVIB, CARE) or Quasi NGOs such as SNV

- Ministries, such as of Ministry of Economic Affairs, Ministry of Foreign Affairs

- Governments (National, Regional, local / cities)

Potential clients require knowledge about:

- Social, economic and environmental effects of climate change/ variability and risks on their business

- Promising adaptation measures which are cost effectiveness, resource efficient and climate smart 


\section{$4 \quad$ References}

Bhadwal, S., Groot, A., Balakrishnan, S., Nair, S., Ghosh, S., Lingaraj, G.J., van Scheltinga, C.T., Bhave, A. and Siderius, C., 2013. Adaptation to changing water resource availability in Northern India with respect to Himalayan Glacier retreat and changing monsoons using participatory approaches. Science of the Total Environment, 468, pp.S152-S161.

Biemans, H., 2012. Water constraints on future food production. Thesis, Wageningen University, The Netherlands. With references, with summaries in English and Dutch. ISBN 978-94-6173-357-3

Biesbroek, G.R., Swart, R.J., Carter, T.R., Cowan, C., Henrichs, T., Mela, H., Morecroft, M.D. and Rey, D., 2010. Europe adapts to climate change: comparing national adaptation strategies. Global environmental change, 20(3), pp.440-450.

Blomsma, C., F. Claassen, P. van de Graaff, F. Uitterhoeve, E. Moors, A. de Groot, J. Rooker en K. de Bruin (2016). Rapport Scenario workshop "Uw voedselproductie in 2050: klimaatneutraal?" gehouden op 20 Mei 2016 ter gelegenheid van de VERNOF jaarvergadering in samenwerking met MVO - de ketenorganisatie voor oliën en vetten, Het Comité van Graanhandelaren, FNLI en Wageningen Universiteit \& Research. Website: https://www.wur.nl/nl/nieuws/Voedselproductie-in-2050-1.htm

Bornventure I. Mumia, James W. Muthomi, Rama D. Narla, Moses W. Nyongesa and Florence M. Olubayo. Seed Potato Production Practices and Quality of Farm Saved Seed Potato in Kiambu and Nyandarua Counties in Kenya. World Journal of Agricultural Research. 2018; 6(1):20-30. doi: 10.12691/wjar-6-1-5

CICERO, 2017. Shades of climate risk - Categorizing climate risks for investors. CICERO Climate Finance

Coninx, I., Bruin, de K., Teuling, Gerard, Heiden, van der A. (2017). Agrifood op naar climate proof. https://library.wur.nl/WebQuery/wurpubs/543807

CRIS, 2017. Climate Risk Impact Screening. The methodological guidebook. Carbone4

Groot, A., Werners, S., Regmi, B., Biemans, H., Gioli, G., Hassan, T., Mamnun, N., Shah, H., Ahmad, B., Siderius, C., Singh, T., Bhadwal, S., Wester, P. (2017). Critical climate-stress moments and their assessment in the Hindu Kush Himalaya: Conceptualization and assessment methods. HI-AWARE Working Paper 10. Kathmandu: HI-AWARE

A.E. Groot, J.S. Bolt, H.S. Jat, M.L. Jat, M. Kumar, T. Agarwal, V. Blok, Business models of SMEs as a mechanism for scaling climate smart technologies: The case of Punjab, India, Journal of Cleaner Production, Volume 210, 2019, Pages 1109-1119, ISSN 0959-6526, https://doi.org/10.1016/j.jclepro.2018.11.054.

Goosen, H. (forthcoming). Interactive Climate Atlas Kenya.

Hutjes, R.W.A., 2011. Climate data processing chain. Retrieved december 2018 from IS-ENES climate for impacts portal:

https://climate4impact.eu/impactportal/documentation/guidanceandusecases.jsp?q=generic_work_flo w

Hutjes, R.W.A., 2017. Indicators for Global Agriculture, Copernicus Climate Change Service, service design mock-up.

IPCC, 2018. Special Report: Global Warming of $1.5^{\circ} \mathrm{C}$. https://www.ipcc.ch/sr15/ 
Ligtvoet W., 2018. The Geography of Future Water Challenges, The Hague: PBL Netherlands Environmental Assessment Agency.

OECD (2007). Climate Change Projections, Sahel and West Africa;

http://www.oecd.org/swac/topics/siccs.htm

Olsson, J.; Arheimer, B.; Borris, M.; Donnelly, C.; Foster, K.; Nikulin, G.; Persson, M.; Perttu, A.-M.; Uvo, C.B.; Viklander, M.; Yang, W. Hydrological Climate Change Impact Assessment at Small and Large Scales: Key Messages from Recent Progress in Sweden. Climate 2016, 4, 39.

Verzandvoort, S., Kuikman, P., Slier, T., Walvoort, D., De Jong, A., Van Randen, Y., Rietra, R. Lesschen, J.P., 2017. CSA Solutions Database (SDB) and Spatial Solution Finder (SSF); Deliverable under the KAVA ID 1.2.6_Flagship: CSAb report SDB-SSF. Wageningen, Wageningen Environmental Research, Report.

Werners, S., Bhadwal, S., Ahmad, B., Gioli, G., Regmi, B., Pandey, A., Mamnun, N., Hassan, T., Varma, N., Ahmed Saeed, B., 2018. Identifying and analysing adaptation turning points in the Hindu Kush Himalayan region. HI-AWARE Working Paper 18. Kathmandu: HI-AWARE 


\section{Annexes: Questionnaires}

\subsection{Step 1.1 - Questionnaire Value chain mapping}

Output: Value chain map showing actors, activities, geographic locations

How: literature review and interviews

\begin{tabular}{|c|}
\hline Questions for different stakeholders in a value chain \\
\hline Who are growing the crop (male / female)? \\
\hline $\begin{array}{l}\text { Are there any practices or crops that are more important for men and women of different age } \\
\text { groups? }\end{array}$ \\
\hline What types of growers can be distinguished? (rainfed, small, large, access to market etc. ) \\
\hline $\begin{array}{l}\text { How are farmers organised? (informal groups, formal cooperatives?). What do they do together? } \\
\text { (sales, inputs, savings?) }\end{array}$ \\
\hline Who are relevant input dealers (providing knowledge, funding, seeds, fertilisers, machineries) \\
\hline Which (types of) traders can be identified? \\
\hline Which processing companies can be identified? \\
\hline Which brokers can be identified? \\
\hline Which buyers can be identified regionally? \\
\hline Which buyers can be identified nationally? \\
\hline Which buyers can be identified internationally? \\
\hline $\begin{array}{l}\text { Are women involved in your value chain? In what way? Do women benefit equally from their } \\
\text { involvement? }\end{array}$ \\
\hline What is the average age of the farmers? \\
\hline What is the average age of the processors? \\
\hline Why are women/youth (not) involved? If so, why do they benefit less? \\
\hline $\begin{array}{l}\text { In the production of this crop, what are the main tasks and responsibilities for women and men in } \\
\text { the farming household? }\end{array}$ \\
\hline Who is responsible for marketing and selling the crop? \\
\hline How are decisions taken on crop production, sales and use of income (male - female - shared?) \\
\hline How many female headed households are engaged in the production? \\
\hline $\begin{array}{l}\text { How could women/youth become more involved in your opinion? How can they benefit more from } \\
\text { their involvement? }\end{array}$ \\
\hline
\end{tabular}




\subsection{Step 1.2 - Questionnaire Identification climate variables}

Output: $\quad$ Specific climate variables relevant to actors in the value chain. Climate change projections will be done for a set of priority climate variables

How: Interviews informed by literature review

\section{Questions for farmers (separate for males, females, under and over $\mathbf{3 5}$ years)}

What climate or weather related hazard (s) is affecting your crop?

How did the frequency and intensity of these hazards change over time?

Which of these hazards has the greatest impact on your crop and why?

Which crops are most/least affected?

Is the climate/weather related hazard(s) affecting your crop at specific crop stages? What are these critical crop stages? (e.g. sowing, germination, flowering, fruit setting, harvesting, storage). Pleas respond for the main hazards affecting the crop

Is daily temperature more important to look at than night temperature?

Do these climate /weather related hazards occur more often than before (for elderly you can this question for the last 10 years)

Are female farmers affected by climate related hazards the same as or different than male farmers? Are female farmers affected at the same moment or at different moments during the cropping cycle?

Are you interested in receiving information about how the climate will change in the future. i.e. for 2050 ? And what about for 2080 ?

If you are interested in receiving information about how the climate will change in the future, please select the six most relevant climate variables of the list below on which you want to receive climate change information about:

\section{Temperature (examples)}

- Max temperature (day)

- Average min temperature (night)

- Number of consecutive days with high temperature

- Number of days with frost

- Other?

\section{Precipitation (examples)}

- Average rainfall (mm/ month)

- Largest number of consecutive wet days

- Largest number of consecutive dry days

- Onset of long/short rainy season(s)

- $\quad$ End of long/short rainy seasons(s)

- Other?

\section{Air humidity}

Air humidity during harvesting / storage

Other? 


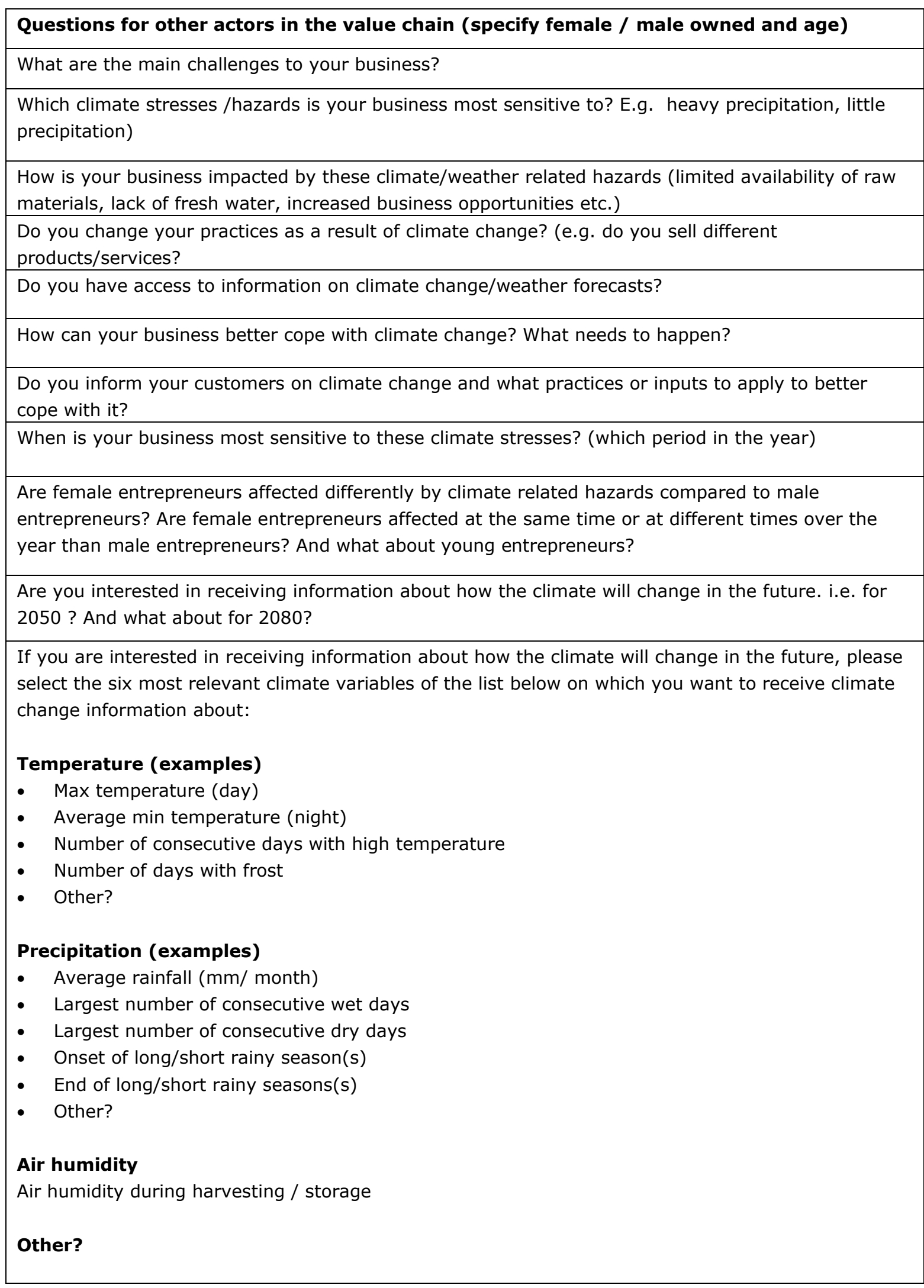




\section{Questions for climate / agricultural experts / literature search}

Which crop stages are most sensitive to climate/ weather related hazards?

Which climate /weather related hazard(s) is the crop most sensitive to in these stages?

Do these climate related hazards occur more often or more severe than in the past (e.g over the last 10 years)

How are these hazards likely to evolve in future climate change scenarios? (for different RCPs if possible) Please select max. 6 most important climate variables of the list below for which it is useful to receive climate change information about:

\section{Temperature}

- $\quad$ Average temperature

- max temperature (day)

- Average min. temperature (day)

- Average min temperature (night)

- Number of consecutive days with temperature $>25^{\circ} \mathrm{C}$ (exact number depends on value chain)

- Other?

\section{Precipitation}

- $\quad$ Average rainfall ( $\mathrm{mm} / \mathrm{month})$

- $\quad$ Average daily intensity $(\mathrm{mm})$

- $\quad$ Largest number of consecutive wet days

- Largest number of consecutive dry days

- Rainfall exceeding the 95 percentile

\section{Air humidity}

Air humidity during harvesting / storage

Other? 


\subsection{Step 2.3 - Assessment of climate change impact on water availability and crop production}

Output: Insight into how climate change is likely to impact water availability and crop production How: $\quad$ Use of existing literature and interviews with key informants

\section{Considerations and key questions to address}

1. What are the major climate/ weather related hazards actors in the chain are experiencing?

How: Discussions on climate variables (CV) give an indication on climate / weather related hazards different actors are experiencing. The CVs allows to be more specific than using generally stated hazards such as drought or heat stress.

2. What is known from literature and expert knowledge how these hazards / climate variables have changed over years and how they are likely to change due to CC (use different climate scenarios for this)

How: Make use of existing literature, such as the literature scan carried out in the context of the CSA /EA project (OneDrive share, but also talk to 2-3 climate change experts and/or agronomist. Try to be as specific as possible and make use of the identified thresholds (e.g. temperature exceedance of $27^{\circ} \mathrm{C}$ during germination stage of common bean in Tanzania). An example of a table which could be developed is the following:

Table 6: Changes in various weather phenomena in Uganda since 1960 (Source: te Pas, 2017. Climate Risk Assessment Uganda)

\begin{tabular}{|l|l|}
\hline Indicators & Changes since $\mathbf{1 9 6 0}$ \\
\hline Temperature & $+1.3^{\circ} \mathrm{C}$ \\
\hline Hot days & +20.4 days/year \\
\hline Hot nights & +37.4 days/year \\
\hline Cold days & -20 days/year \\
\hline Cold nights & -42 days/year \\
\hline Rainfall & $-3.5 \%$ month \\
\hline Heavy rainfall events & no significant changes \\
\hline
\end{tabular}

3. What is known from literature and expert knowledge how these changes in hazards / climate variables have impacted the water availability and crop production

How: Focus on the geographic area(s) identified through the value chain mapping. Make use of existing literature, amongst others the literature scan carried out in the context of the CSA /EA project (see google drive) but also talk to 2-3 climate change experts and/or agronomists or organise a focus group discussion.

A type of figure which could be developed is: 


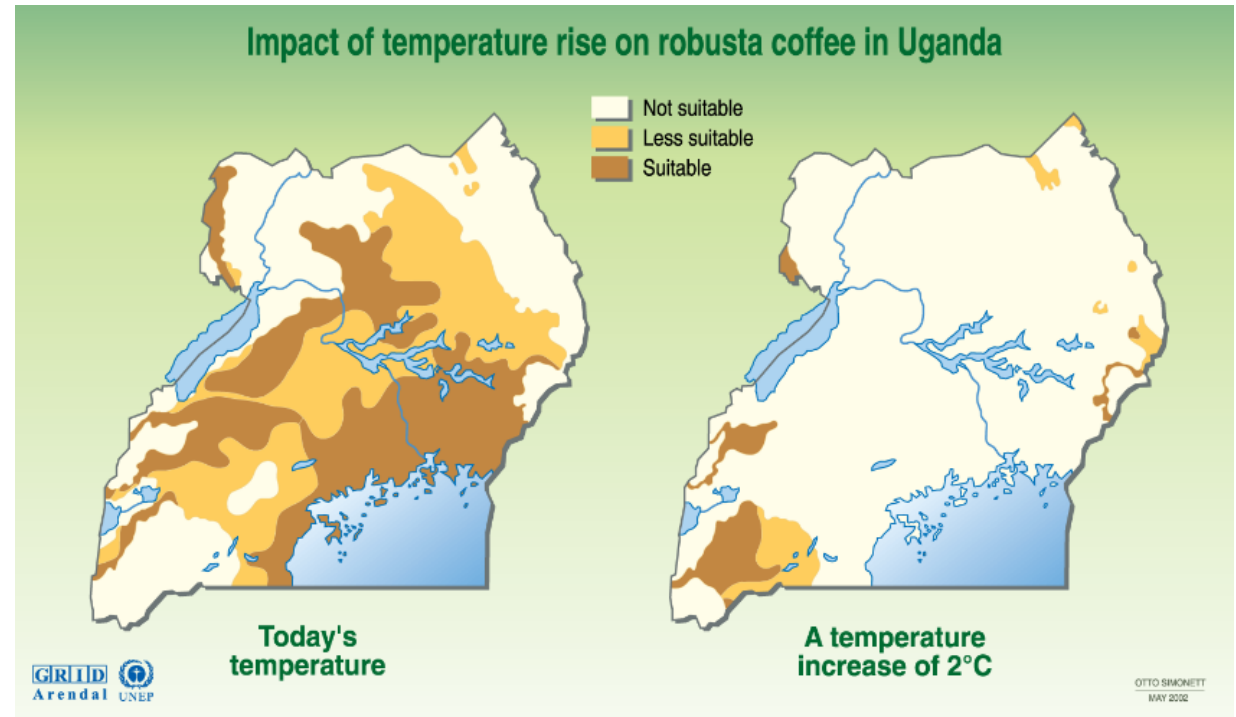

Figure 13 : Impact of CC on Coffee production in Uganda (Source: te Pas, 2017. Climate Risk Assessment Uganda) 


\subsection{Step 3.1 - Identification of potential climate /weather related risks}

Output: $\quad$ Potential climate/weather related risks on livelihood and/or business due to climate change induced changes in water availability and crop production

How: Interviews with actors in the value chain. Conduct interviews with men, women, under and over 35 and note gender and age. Interview results will be further discussed in climate risks assessment workshop

\begin{tabular}{|c|c|c|c|c|}
\hline Questions & $\begin{array}{l}\text { Impact due } \\
\text { to climate } \\
\text { induced } \\
\text { changes in } \\
\text { water } \\
\text { availability } \\
\text { and crop } \\
\text { production }\end{array}$ & $\begin{array}{l}\text { Adaptation } \\
\text { strategy }\end{array}$ & $\begin{array}{l}\text { Effectiveness of } \\
\text { adaptation } \\
\text { strategy to } \\
\text { mitigate } \\
\text { impact }\end{array}$ & $\begin{array}{l}\text { Potential } \\
\text { climate } \\
\text { /weather } \\
\text { related risk } \\
\text { (yes/no) }\end{array}$ \\
\hline Questions for farmers (males, females, youngsters) & & & & \\
\hline $\begin{array}{l}\text { Looking at the likely change in available water due to } \\
\mathrm{CC} \text {, how might this affect your livelihood /family. } \\
\text { What kind of measures / strategies do you use to } \\
\text { mitigate these risks? }\end{array}$ & & & & \\
\hline $\begin{array}{l}\text { Looking at the likely change on crop production } \\
\text { (quantitatively, qualitatively, availability, suitable } \\
\text { areas). How would it change your farming business. } \\
\text { Can you estimate the losses ( minor, moderate, } \\
\text { major). What kind of measures / strategies do you } \\
\text { use to mitigate these risks? }\end{array}$ & & & & \\
\hline $\begin{array}{l}\text { Considering other risks you are facing such as health, } \\
\text { changing market prices, do you consider the fore- } \\
\text { mentioned risks due to CC minor, moderate or major } \\
\text { risks? What kind of measures / strategies do you use } \\
\text { to mitigate these risks? }\end{array}$ & & & & \\
\hline $\begin{array}{l}\text { Do you see new opportunities due to changing water } \\
\text { availability and/or crop production? }\end{array}$ & & & & \\
\hline $\begin{array}{l}\text { Questions for other actors in value chain (males, } \\
\text { females, youngsters)? }\end{array}$ & & & & \\
\hline $\begin{array}{l}\text { Looking at the likely CC impact on crop production } \\
\text { (quantitatively, qualitatively, availability, suitable } \\
\text { areas) how will this affect your business? (e.g. } \\
\text { estimation decline in income in \%). What kind of } \\
\text { measures / strategies do you use to mitigate these } \\
\text { risks? }\end{array}$ & & & & \\
\hline $\begin{array}{l}\text { Considering the likely impact on water resources } \\
\text { availability, how will this affect your business? (e.g. } \\
\text { estimation decline in income in \%). What kind of } \\
\text { measures / strategies do you use to mitigate these } \\
\text { risks? }\end{array}$ & & & & \\
\hline
\end{tabular}




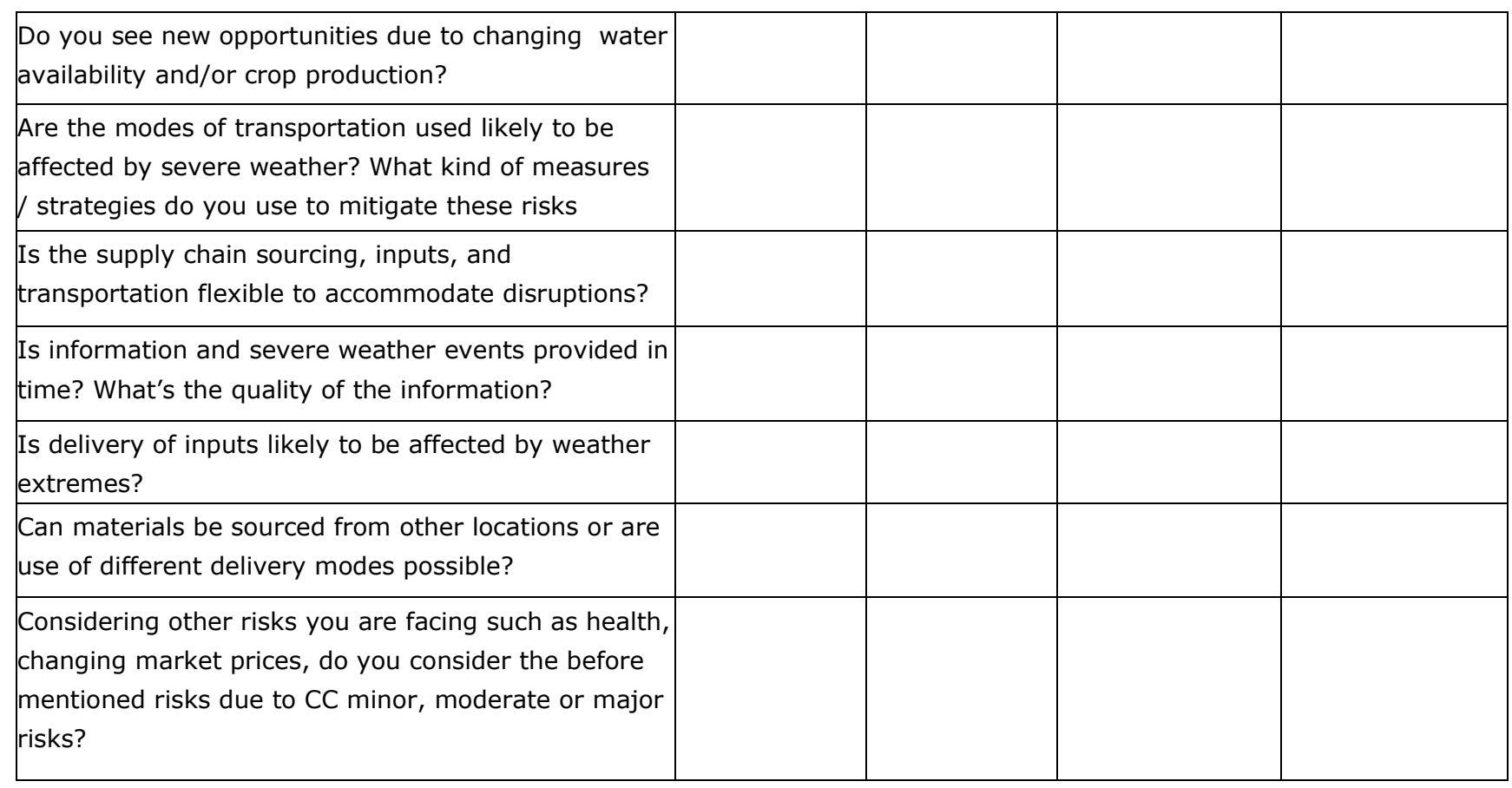




\subsection{Step 3.2 - Risk prioritisation}

Output: $\quad$ Climate related risks prioritised

How: $\quad$ Preparatory interviews with actors in the value chain (specify for men, women, under and over 35 and conduct separate interviews) and climate experts. Interview results will be further discussed in climate risks assessment workshop.

\section{Questions for climate experts}

What's the likelihood of a particular risk to occur in future?

( $1=$ very low, $2=$ low, $3=$ moderate , $4=$ high, $5=$ very high)

\section{Questions for all actors in the value chain}

- Assuming the potential risk we just discussed will occur, what would be the impact of it on your livelihood / business?

- Do you consider the impact to be (1= insignificant, $2=$ minor, $3=$ moderate, $4=$ major, $5=$ catastrophic)?

- Considering experts' expectations concerning the likelihood of occurrence of the various risks, which risks are most important? 
Wageningen Environmental Research P.O. Box 47

6700 AA Wageningen

The Netherlands

$\mathrm{T}+31(0) 317480700$

www.wur.nl/environmental-research

Wageningen Environmental Research Report

ISSN 1566-7197
The mission of Wageningen University and Research is "To explore the potential of nature to improve the quality of life". Under the banner Wageningen University \& Research, Wageningen University and the specialised research institutes of the Wageningen Research Foundation have joined forces in contributing to finding solutions to important questions in the domain of healthy food and living environment. With its roughly 30 branches, 5,000 employees and 10,000 students, Wageningen University \& Research is one of the leading organisations in its domain. The unique Wageningen approach lies in its integrated approach to issues and the collaboration between different disciplines. 